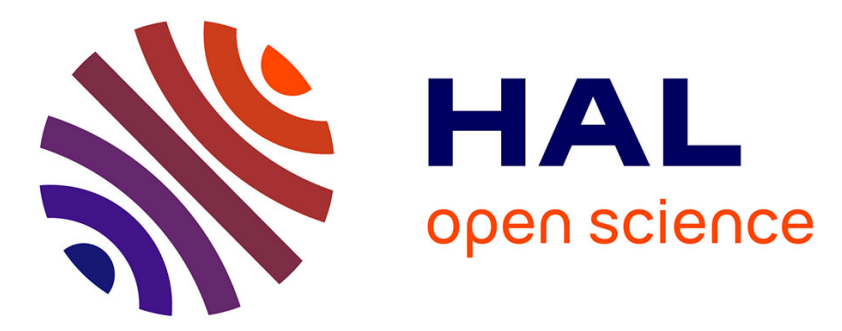

\title{
Metasomatic interactions between slab-derived melts and depleted mantle: Insights from xenoliths within Monglo adakite (Luzon arc, Philippines)
}

M. Grégoire, Sébastien Jégo, René Maury, Betchaida D. Payot, Rodolfo A. Tamayo, Graciano P. Yumul

\section{To cite this version:}

M. Grégoire, Sébastien Jégo, René Maury, Betchaida D. Payot, Rodolfo A. Tamayo, et al.. Metasomatic interactions between slab-derived melts and depleted mantle: Insights from xenoliths within Monglo adakite (Luzon arc, Philippines). Lithos, 2008, 103 (3-4), pp.415-430. 10.1016/j.lithos.2007.10.013 . insu-00256478

\section{HAL Id: insu-00256478 \\ https://hal-insu.archives-ouvertes.fr/insu-00256478}

Submitted on 27 Mar 2008

HAL is a multi-disciplinary open access archive for the deposit and dissemination of scientific research documents, whether they are published or not. The documents may come from teaching and research institutions in France or abroad, or from public or private research centers.
L'archive ouverte pluridisciplinaire HAL, est destinée au dépôt et à la diffusion de documents scientifiques de niveau recherche, publiés ou non, émanant des établissements d'enseignement et de recherche français ou étrangers, des laboratoires publics ou privés. 


\title{
Metasomatic interactions between slab-derived melts and depleted mantle: Insights from xenoliths within Monglo adakite (Luzon arc, Philippines)
}

\author{
M. Gregoire ${ }^{a}$, S. Jego ${ }^{b}$, R.C. Maury ${ }^{c}$, M. Polve ${ }^{d}$, B. Payot ${ }^{e}$, R.A. Tamayo Jr. ${ }^{f}$ and G.P. \\ Yumul Jr. ${ }^{e, f}$
}

UMR 5562 DTP, Observatoire Midi-Pyrénées, Université Paul Sabatier, 14 rue Edouard Belin, 31400

Toulouse, France

${ }^{\text {b} U M R ~} 6113$ CNRS/INSU, Université d'Orléans, Institut des Sciences de la Terre d'Orléans, 45067, Orléans, France

'UMR 6538 Domaines Océaniques, Université de Bretagne Occidentale, 6, avenue Le Gorgeu, C.S. 93837, 29238 Brest Cedex 3, France

${ }^{\mathrm{d}}$ LMTG-Université de Toulouse-CNRS-IRD-OMP, 14 rue Edouard Belin, 31400 Toulouse, France ${ }^{\mathrm{e}}$ National Institute of Geological Sciences, University of the Philippines, Diliman, 1101 Quezon City, Philippines

${ }^{\mathrm{f}}$ Philippine Council for Industry and Energy Research and Development-DOST, Gen. Santos Avenue, Bicutan, 1631 Taguig, Philippines

\begin{abstract}
The Monglo adakite contains mafic and ultramafic xenoliths, which probably originated from the mantle section of an Early Cretaceous supra-subduction zone ophiolitic complex located within the Luzon arc crust. Spinel-bearing dunites are dominant among this xenolith collection and display evidence for three episodes of subduction-related melt percolation. The first one is evidenced by an undeformed clinopyroxene characterized by convex-upwards REE pattern. This clinopyroxene crystallized from a calc-alkaline basaltic magma, likely formed in the Cretaceous supra-subduction setting of the ophiolite. Then, two metasomatic events, evidenced by orthopyroxene-rich and amphibole-rich secondary parageneses, respectively, affected most of the spinel dunites. The opx-rich paragenesis is related to the circulation within the dunitic upper mantle of hydrous slab-derived melts similar to those affecting the mantle peridotite xenoliths from Papua New Guinea and Kamchatka. Finally the amphibole-rich veins are related to the interaction between the studied dunite xenoliths and the host adakite or an adakitic melt similar to it.
\end{abstract}

Keywords: Mantle xenoliths; Luzon arc; Metasomatism; Dunite; Trace elements; Adakite 


\section{Introduction}

Deep-seated xenoliths sampled by volcanic rocks represent a major and direct source of information on the nature, the composition and the evolution of the deep crust and upper mantle in continental and oceanic settings (e.g., [Nixon, 1987], [O'Reilly and Griffin, 1987], [Coltorti et al., 1999], [Ionov and Hofmann, 1995], [Ionov et al., 1999], [Grégoire et al., 1997], [Grégoire et al., 1998], [Grégoire et al., 2000] and [Grégoire et al., 2005]). For a long time they were found almost exclusively in intraplate settings, especially within alkali basalts and related lavas ([Mercier and Nicolas, 1975] and [Nixon, 1987]). Indeed, most of the xenoliths collected within subduction-related magmatic rocks are either mafic cognate xenoliths which evidence magma mixing processes (Coulon et al., 1984) or plutonic blocks and cumulate rocks derived from the crystallization or fractionation at depth of calc-alkaline magmas (Arculus and Wills, 1980). However, several occurrences of mantle xenoliths within arc lavas have been described ([Abe et al., 1998], [Arai et al., 2000], [Arai et al., 2003], [Smith et al., 1999], [Brandon and Draper, 1996], [Luhr and Aranda-Gomez, 1997], [Grégoire et al., 2001] and [McInnes et al., 2001]). For instance, the phlogopite- and kaersutite-bearing xenoliths from Batan island in the northern Philippines allow to document metasomatic processes in the mantle wedge involving hydrous fluids ([Vidal et al., 1989] and [Maury et al., 1992]) and adakitic melts ([Schiano et al., 1995] and [Arai et al., 2004]). The mantle xenoliths from Lihir in Papua New Guinea ([McInnes et al., 2001] and [Grégoire et al., 2001]) consist of fibrous, radiating orthopyroxene and fine-grained $\mathrm{Fe}-\mathrm{Ni}$ sulfide with minor olivine, clinopyroxene, phlogopite, amphibole and magnetite. These metasomatic minerals precipitated from a hydrous melt characterized by low HFSE contents ([McInnes et al., 2001] and [Grégoire et al., 2001]). These authors proposed that some arc magmas could originate from partial melting of mantle wedge regions metasomatised by such HFSE-poor, slabderived hydrous melts.

The present paper focuses on the metasomatic parageneses and major and trace element characteristics of a set of five fresh dunite xenoliths hosted by the Monglo adakite in the Baguio District, Northern Luzon, which provide an analogue for metasomatism of depleted mantle by slab-derived hydrous melts (adakitic liquids). A less focused companion paper published in Island Arc (Payot et al., 2007) describes the Monglo adakite and the whole suite of mafic and ultramafic xenoliths entrained by the latter (spinel dunites, serpentinites derived from them, amphibolites, gabbros and a single quartz diorite).

\section{Host lava and petrography}

The Monglo adakite ([Jego et al., 2005] and [Payot et al., 2007]) is a small intrusive body located $16 \mathrm{~km}$ northwest of Baguio City in Northern Luzon (N16 28'52; E120 $29^{\prime} 55$, altitude $720 \mathrm{~m}$ ). A quarry along the Naguilian road near Monglo village exposes a ca. $50 \mathrm{~m}$ thick hornblende-bearing dacitic intrusive sheet dated at $8.65 \pm 0.24 \mathrm{Ma}$ (Jego et al., 2005). It crosscuts the Klondyke Formation (Fig. 1), a Middle to Late Miocene sequence of coarse clastic rocks, polymictic conglomerates, sandstones and vitric tuffs, with minor shales and siltstones (Tamesis et al., 1982). The geochemistry of this dacite has been discussed by Jego et al. (2005), who consider it as a "typical" or "genuine" adakite derived from ca. $20 \%$ hydrous partial melting of altered oceanic metabasalts converted to eclogite. It displays very low $\mathrm{Y}$ and $\mathrm{Yb}$ values approximating those of the primitive mantle (Sun and McDonough, 1989), highly fractionated rare earth element (REE) patterns and $\mathrm{Sr} / \mathrm{Y}$ ratio of 130-150, a diagnostic feature for adakites (Defant and Drummond, 1990). Like many adakites, it contains 
relatively high amounts of $\mathrm{Ni}(50-53 \mathrm{ppm}), \mathrm{Co}(14-17 \mathrm{ppm})$ and $\mathrm{Cr}(62-84 \mathrm{ppm})$, which might indicate interactions with its ultramafic xenoliths (Jego et al., 2005).

The Monglo adakite contains numerous xenoliths ranging usually in size from 1 to $10 \mathrm{~cm}$ (Fig. 2D), which includes spinel dunites, serpentinites derived from them, amphibolites, gabbros and a single quartz diorite. The whole xenolith association, including the five mantlederived spinel dunites described in the present study, probably originated from a Lower Cretaceous ophiolitic complex (Payot et al., 2007). Indeed, all the transitions between "fresh" dunites and completely serpentinized ones (lizardite/chrysotile-bearing) can be found, as usual in the mantle section of ophiolitic massifs. Serpentinization occurred before the incorporation of these xenoliths within the adakitic magma, as evidenced by the contact between serpentinite xenoliths and the host adakite which is typically a reaction rim of rather constant thickness $(\sim 0.5 \mathrm{~mm})$ consisting of a coating of fibrous antigorite and amphibole (actinolite/tremolite) growing perpendicularly to the contact (see Fig. 2 of Payot et al., 2007) As lizardite/chrysotile form under relatively low-temperature conditions while antigorite is a higher-temperature serpentine (Evans, 1977), we ascribe this reaction rim to thermal metamorphism of the already serpentinized dunites by the host (serpentine-free) adakite. The gabbros display adcumulate textures, primary mineral associations and major and trace element compositions, especially flat to moderately enriched incompatible trace element patterns similar to those of gabbros derived from back-arc basin basalt (BABB) magmas (Payot et al., 2007). Associated amphibolites are considered derived from metapicrites and/or metagabbros of similar affinity. A single quartz diorite xenolith also carrying a BABB-related geochemical signature has been sampled. One amphibolite xenolith provided a whole rock $\mathrm{K}-$ Ar age of $115.6 \pm 8.33 \mathrm{Ma}$ (Barremian). As a whole, this xenolith association could represent an equivalent of the Early Cretaceous Isabela-Aurora and Pugo-Lepanto MORB- to BABBtype ophiolitic massifs exposed in Northern Luzon ([Tamayo et al., 2004], [Pubellier et al., 2004] and [Andal et al., 2005]), as well as of the Barremian oceanic crust of the adjacent Huatung Basin (Deschamps et al., 2000).

The five studied "fresh" dunites (samples $01 \mathrm{c} 01,08 \mathrm{Ja}, 08 \mathrm{Jb}, 08 \mathrm{Jc}, 08 \mathrm{Jd}$ ) are primarily made up of olivine showing protogranular texture (Mercier and Nicolas, 1975) with the exception of sample $08 \mathrm{Jb}$ which displays a porphyroclastic texture. Olivine crystals are well-preserved, and show curvilinear edges and undulose extinction. Grain size reaches up to $>5 \mathrm{~mm}$. Primary orthopyroxenes (Opx1) only occur in small amounts (less than 2-3\%) in samples 08Je and 08Jf. Rare clinopyroxene crystals (less than 2-3\%) have been only observed in sample $01 \mathrm{c} 01$ where they occur as undeformed anhedral grains filling the interstices between the primary deformed olivines (Fig. 2A). Brownish to black spinels are also present as anhedral to subhedral isolated coarse crystals $(>1 \mathrm{~mm})$ or in smaller grains usually gathered in clusters. These spinels commonly display a rim darker than the core of the crystal. Four studied dunite xenoliths also display small interstitial patches (especially around spinel) and/or thin veins ( $<1 \mathrm{~mm}$ wide) filled with secondary minerals. Shear structures are not observed in the veins. They are dilational in nature and are assumed to have formed via hydraulic fracturing. Two secondary mineral parageneses which do not coexist in a given sample have been observed: (i) fibrous orthopyroxene + minor phlogopite and sulfides (samples 08Ja and 08Jb) and (ii) amphibole + minor phlogopite, green spinel and sulfides (samples 08Je and 08Jf). Samples 08Ja and $08 \mathrm{Jb}$ display crosscutting networks of orthopyroxene-rich veins containing a secondary mineral assemblage consisting of fibrous, radiating orthopyroxenes (Opx2) often showing euhedral edges and associated to minor phlogopite (Phl-a) crystals and fine-grained Fe-Ni sulfides (Fig. 2B). Samples 08Je and 08Jf also show crosscutting networks of veins but 
these veins are amphibole-rich. They contain a secondary mineral assemblage consisting of euhedral to subhedral amphiboles associated to minor phlogopite crystals (Phl-b), rounded green spinel grains (Sp2) and fine-grained Fe-Ni sulfides (Fig. 2C). In the case of the opxrich veins, euhedral terminations of orthopyroxene in the fracture networks indicate that they grew unrestricted into melt-filled cavities within the mantle prior to xenolith incorporation in the lava. The two metasomatic parageneses also occur in patches surrounding the primary spinels displaying rims darker than their cores. Trails of secondary inclusions containing a liquid phase, a vapour phase, and various daughter minerals occur within primary olivine grains adjacent to the metasomatic veins. Sample $01 \mathrm{cl}$ only contains very rare and tiny phlogopites (in addition to undeformed interstitial clinopyroxene grains) and it is therefore difficult to classify this sample in one of the two above groups. Some evidence of hydraulic fracturing has been observed in sample $08 \mathrm{Jb}$, in which fragments of primary olivines occur within aggregates of fibrous orthopyroxenes (Fig. 2).

\section{Analytical techniques}

Mineral analyses from the dunite xenoliths were done using a Cameca SX50 electron microprobe at the Electronic Microprobe Service, Université Paul Sabatier, Toulouse, France. Operating conditions were set at $15 \mathrm{kV}, 10 \mathrm{nA}$ and $10 \mathrm{~s}$ counting time, using natural and synthetic standards for calibration.

Concentrations of trace elements and REE ( $\mathrm{La}, \mathrm{Ce}, \mathrm{Nd}, \mathrm{Sm}, \mathrm{Eu}, \mathrm{Gd}, \mathrm{Dy}, \mathrm{Ho}, \mathrm{Er}, \mathrm{Yb}, \mathrm{Lu}, \mathrm{Rb}$, $\mathrm{Ba}, \mathrm{Th}, \mathrm{U}, \mathrm{Sr}, \mathrm{Zr}, \mathrm{Hf}, \mathrm{Nb}, \mathrm{Ta}, \mathrm{Ti}, \mathrm{Ni}, \mathrm{V})$ were determined by laser ablation inductively coupled plasma mass spectrometer (La-ICP-MS), at the ICP-MS common service, Observatoire Midi-Pyrénées (Université Paul Sabatier, Toulouse). This allowed in situ analysis of clinopyroxene (Cpx) on $>120 \mu \mathrm{m}$ thick polished sections. The Perkin Elmer 6000 ICP-MS instrument was coupled to a Cetac LSX-200 laser ablation module that uses a $266 \mathrm{Nm}$ frequency-quadrupled Nd-YAG laser. The NIST 610 and 612 glass standards were used for external calibration. Amphibole analyses were normalized using $\mathrm{CaO}$ values determined by electron microprobe while those of clinopyroxene and orthopyroxene were normalized using $\mathrm{MgO}$ values. Ablation was operated on the inter-cleavage domains from the cores of the freshest grains, in order to obtain homogeneous results unaffected by alteration or exsolution processes. A beam diameter of $50-100 \mu \mathrm{m}$ and a scanning rate of $20 \mu \mathrm{m} / \mathrm{s}$ were used. Typical theoretical detection limits range from 10 to $20 \mathrm{ppb}$ for REE, Ba, Rb, Th, Sr, Zr and $\mathrm{Y}$; $100 \mathrm{ppb}$ for $\mathrm{Sc}$ and $\mathrm{V}$; and $2 \mathrm{ppm}$ for $\mathrm{Ti}$ and $\mathrm{Ni}$. The relative precision and accuracy for laser analyses range from 1 to $10 \%$.

\section{Results}

\subsection{Primary mineralogy (Table 1 and Table 2)}

The primary (i.e. pre-metasomatic patches and veins) mineral association of the studied dunites has been already analysed by Payot et al. (2007) and therefore we only recall here its main features. The olivines are highly magnesian with $\mathrm{Mg} \#\left[=100 \mathrm{Mg} / \mathrm{Mg}+\mathrm{Fe}_{\text {total }}\right]$ values ranging from 89.8 to 91.2 , associated to high $\mathrm{NiO}$ contents ranging from 0.31 to $0.39 \mathrm{wt} . \%$ (Table 1). Orthopyroxenes also exhibit a very high $\mathrm{Mg} \#(89.7-92)$ and a relatively high $\mathrm{Al}_{2} \mathrm{O}_{3}$ content (4.1-4.5 wt.\%). Clinopyroxene, which only occurs in sample $01 \mathrm{c} 01$, is a highly magnesian Cr-diopside ( $\mathrm{Mg \# :} 94.5$ and $\mathrm{Cr}_{2} \mathrm{O}_{3}=1.5 \mathrm{wt} . \%$ ) containing rather high amounts of $\mathrm{Al}_{2} \mathrm{O}_{3}$ and $\mathrm{Na}_{2} \mathrm{O}$ (4.4 and 0.8 wt.\%, respectively). All these compositions are typical of mantle rocks and mantle xenoliths (Payot et al., 2007). The spinels show a wide range of $\mathrm{Cr} \#$ 
$(=100 \times \mathrm{Cr} /[\mathrm{Cr}+\mathrm{Al}])$ values $(2.9-72)$ as well as of corresponding $\mathrm{Mg} \#$ values (23.7-75.5), but as a whole their core compositions ( $\mathrm{Mg}-\mathrm{Al}$ chromites) are also typical of mantle peridotites (Payot et al., 2007). The spinel rims systematically display a higher Cr\# and a lower $\mathrm{Mg} \#$ than the corresponding cores. In the diagram displaying $\mathrm{Cr} \#$ spinel vs Fo content of olivine (Fig. 3) the five Monglo dunites plot within the olivine-spinel mantle array (OSMA-[Arai, 1994] and [Arai et al., 2004]). They also display similarities with the Moho transition zone dunites from the Philippines ophiolites (Tamayo et al., 2004) and the Batan peridotite mantle xenoliths representing samples from the Philippines sub-arc lithospheric mantle (Arai et al., 2004) (Table 2).

The clinopyroxene from sample 01c01 displays a convex-upwards REE pattern $\left(\mathrm{Ce}_{\mathrm{N}} / \mathrm{Yb}_{\mathrm{N}}\right.$ : $\left.1.2 ; \mathrm{Ce}_{\mathrm{N}} / \mathrm{Sm}_{\mathrm{N}}: 0.5 ; \mathrm{Sm}_{\mathrm{N}} / \mathrm{Yb}_{\mathrm{N}}: 2.3\right)$ ranging from two to five times the primitive mantle values (Fig. 4). Its extended trace element pattern is characterized by slight negative $\mathrm{Nb}, \mathrm{Sr}$ and $\mathrm{Ti}$ anomalies (Fig. 4).

\subsection{Metasomatic patches and veins mineralogy (Table 1 and Table 2)}

The secondary orthopyroxenes (Opx2) are also highly magnesian (Mg\#: 92.4-94.8) but display much lower $\mathrm{Al}_{2} \mathrm{O}_{3}$ contents $(0.5-1.7 \mathrm{wt} . \%)$ than the primary orthopyroxene (Opx1). The phlogopites associated with $\mathrm{Opx} 2$ are lower in $\mathrm{Al}_{2} \mathrm{O}_{3}$ than those associated with amphibole (14.94 and 16.9-17.7 wt.\%, respectively) for similar high Mg\# (91.8 and 91.992.3, respectively). In both cases $\mathrm{TiO}_{2}$ content is very low (Fig. 5). Based on the $\mathrm{Al}_{2} \mathrm{O}_{3}$ content of its phlogopite ( $14.8 \mathrm{wt} . \%)$ it seems that sample $01 \mathrm{c} 01$ could be classified into the group of samples displaying the opx-rich metasomatic paragenesis. Amphiboles (Amph) are tschermakites characterized by $\mathrm{Mg} \#$ ranging from 87.1 to 89.1 , very low $\mathrm{TiO}_{2}$ contents $(0.2-$ 0.5 wt.\%) and $\mathrm{Al}_{2} \mathrm{O}_{3}$ and $\mathrm{Na}_{2} \mathrm{O}$ contents ranging from 13 to 13.6 wt. $\%$ and from 2.4 to 2.5 wt.\%, respectively (Fig. 5). The green spinels (Sp2) associated to amphiboles are Ti-free Cr-pleonastes.

The fibrous orthopyroxene displays a LREE-depleted pattern $\left(\mathrm{Ce}_{\mathrm{N}} / \mathrm{Sm}_{\mathrm{N}}: 0.3\right.$ and $\mathrm{Ce}_{\mathrm{N}} / \mathrm{Yb}_{\mathrm{N}}$ : $0.2)$ characterized by a slight La-enrichment over $\mathrm{Ce}\left(\mathrm{La}_{N} / \mathrm{Ce}_{\mathrm{N}}: 1.5\right.$; Fig. 6). This pattern is similar in shape to those of the fibrous orthopyroxenes from Lihir mantle peridotite xenoliths (Papua New Guinea, Grégoire et al., 2001) but at a higher concentration level. The corresponding extended incompatible multielement patterns of these samples also display the same negative $\mathrm{Zr}$ and $\mathrm{Ti}$ anomalies and the same positive $\mathrm{U}$ anomaly (Fig. 6). The amphibole shows a LREE-enriched pattern $\left(\mathrm{Ce}_{\mathrm{N}} / \mathrm{Sm}_{\mathrm{N}}: 1.5 ; \mathrm{Ce}_{\mathrm{N}} / \mathrm{Yb}_{\mathrm{N}}: 3.8\right.$; Fig. 7$)$, also similar to those of amphiboles from Lihir mantle xenoliths and from the Finero peridotite massif (Italian Alps, Coltorti et al., 2007). This similarity is also evidenced by the extended incompatible trace element patterns of these samples, which display the same negative $\mathrm{Nb}, \mathrm{Ta}$ and $\mathrm{Ti}$ anomalies (Fig. 7). In this diagram the Monglo amphiboles appear different from the amphiboles of the composite mantle xenoliths from Kerguelen islands (Moine et al., 2001). For example Nb contents of the Kerguelen amphiboles cover a broad range but are systematically higher than those of the Monglo amphiboles (Fig. 7).

\section{Discussion}

The mineral and chemical features of the Monglo dunites are in good agreement with an origin as depleted upper-mantle rocks from subduction-related lithospheric mantle (see above and Payot et al., 2007) incorporated within the ophiolitic basement of Northern Luzon. This 
paper aims to discuss the origin of the secondary orthopyroxene-rich and amphibole-rich metasomatic parageneses, as well as the origin of the undeformed interstitial clinopyroxene occurring in sample $01 \mathrm{c} 01$.

\subsection{Origin of the clinopyroxene from sample 01c01: interaction with basaltic melt}

The shape and undeformed nature of clinopyroxene of dunite $01 \mathrm{c} 01$ clearly indicates that it crystallized from a melt which circulated within the primary (deformed) olivine-rich association of this Moho transition zone dunite (Fig. 2A). We have calculated the composition of the theoretical melt in equilibrium with the clinopyroxene and compared the result with some natural melts. We have used the following set of clinopyroxene/basaltic melt partition coefficients:

\begin{tabular}{|l|l|l|}
\hline $\mathrm{Ti}$ & 0.384 & Hart and Dunn 1993 \\
\hline $\mathrm{Sr}$ & 0.096 & Johnson 1994 \\
\hline $\mathrm{Zr}$ & 0.4 & Forsythe et al., 1994 \\
\hline $\mathrm{Nb}$ & 0.03 & Forsythe et al., 1994 \\
\hline $\mathrm{La}$ & 0.0536 & Hart and Dunn 1993 \\
\hline $\mathrm{Ce}$ & 0.0858 & Hart and Dunn 1993 \\
\hline $\mathrm{Nd}$ & 0.1873 & Hart and Dunn 1993 \\
\hline $\mathrm{Sm}$ & 0.291 & Hart and Dunn 1993 \\
\hline $\mathrm{Eu}$ & 0.41 & Frey, 1969 \\
\hline $\mathrm{Gd}$ & 0.46 & Frey, 1969 \\
\hline $\mathrm{Dy}$ & 0.442 & Hart and Dunn 1993 \\
\hline $\mathrm{Ho}$ & 0.44 & Paster et al., 1974 \\
\hline $\mathrm{Er}$ & 0.39 & Hart and Dunn 1993 \\
\hline $\mathrm{Yb}$ & 0.43 & Hart and Dunn 1993 \\
\hline $\mathrm{Lu}$ & 0.433 & Hart and Dunn 1993 \\
\hline $\mathrm{Th}$ & 0.0127 & Hauri et al., 1994 \\
\hline
\end{tabular}

The REE and extended trace element patterns (Fig. 8) of the theoretical melt in equilibrium with the clinopyroxene of the sample $01 \mathrm{c} 01$ display strong similarities (shapes of the patterns, levels of enrichment, negative $\mathrm{Nb}, \mathrm{Zr}$, Ti anomalies) with those of Neogene low-K to medium-K calc-alkaline basalts from the Luzon arc. A significant basaltic volcanism occurred in the Baguio district from 15.3 to $8 \mathrm{Ma}$ (Polvé et al., 2007). Its initial products were low-K calc-alkaline basalts, which evolved through time by being progressively enriched in $\mathrm{K}$ and other large ion lithophile elements. 
However, the thermal metamorphism of serpentinized dunites by the host adakite implies that the studied dunitic samples were not located in upper-mantle conditions during the Miocene (i.e. they were already tectonically emplaced within the Northern Luzon crust as part of an ophiolitic massif). In such conditions, percolating basaltic melts should be quenched before reacting with the ultramafic rocks to form metasomatic clinopyroxene. We therefore propose that the interstitial undeformed clinopyroxene of the spinel dunite $01 \mathrm{c} 01$ crystallized from a calc-alkaline basaltic magma, which percolated through a high-temperature dunitic upper mantle prior to its obduction and cooling, probably during the Early Cretaceous suprasubduction history of the ophiolite.

\subsection{Dunite metasomatism by adakitic and other slab-related melts}

The other four dunite xenoliths from Monglo evidence modal metasomatic processes highlighted by two types of metasomatic parageneses occurring in crosscutting veins and patches commonly surrounding primary spinels: (i) orthopyroxene-rich paragenesis (samples 08Ja and 08Jb) and (ii) amphibole-rich one (samples 08Je and 08Jf).

The fibrous metasomatic orthopyroxene is characterized by a strong $U$ enrichment and strong HFSE depletions (Nb, Zr, Ti - Fig. 6). This orthopyroxene displays strong major and trace element similarities with the fibrous orthopyroxenes occurring in mantle xenoliths (mostly spinel harzburgites) from the Tubaf and Edison submarine cinder cones located SE of Lihir island (Papua New Guinea; [McInnes et al., 2001] and [Grégoire et al., 2001]) and also with the Al-poor metasomatic orthopyroxenes from Colorado Plateau mantle xenoliths (Smith et al., 1999). These similarities include equivalent (and low) $\mathrm{Al}_{2} \mathrm{O}_{3}$ content, almost identical REE patterns and respectively positive U- and negative HFSE anomalies (Fig. 6). The rare phlogopites associated to fibrous orthopyroxene in Monglo dunites are less magnesian than those from Lihir xenoliths but display similarly low $\mathrm{TiO}_{2}$ content which appears to be characteristic of phlogopite associated to subduction-related metasomatic assemblage (Fig. 5; Coltorti et al., 2007).

The amphiboles occurring in the Monglo dunites are strongly enriched in LREE, and appear to be significant mineral repositories for $\mathrm{Th}, \mathrm{U}$ and $\mathrm{Sr}$ as well. Such features are also documented by Moine et al. (2001) for the amphibole-bearing composite mantle xenoliths from the Kerguelen Islands and by Grégoire et al. (2001 for the amphibole-bearing mantle xenoliths from the Tubaf and Edison volcanoes (Lihir Island, Papua New Guinea). The Monglo amphiboles also display similarities with the S-amphiboles (S: Subduction mantle amphibole) defined by Coltorti et al. (2007) and corresponding to amphibole crystallizing in subduction-related mantle metasomatic assemblages (Fig. 5 and Fig. 7). For example, their $\mathrm{Na}_{2} \mathrm{O}$ contents and their REE- and trace element patterns are similar to those of the Samphibole from Lihir Island and from the Finero peridotite massif (Italian Alps; Fig. 5 and Fig. 7). The rare phlogopites associated to the amphibole are also low in titanium (Fig. 5), as well as those associated to the fibrous orthopyroxene. The metasomatic assemblage from Lihir Island has been related to the percolation of slab-derived, hydrous melts within a previously depleted peridotitic upper mantle ([McInnes et al., 2001] and [Grégoire et al., 2001]). A similar origin has been proposed for the metasomatism affecting the mantle peridotite xenoliths from Batan Island (Schiano et al., 1995) which belongs to the northern section of the Luzon arc ([Defant et al., 1989] and [Defant et al., 1990]). Some of these Batan mantle xenoliths display similar fibrous orthopyroxene-rich assemblages (Arai et al., 2004). To emphasize the similarity between the Lihir and Batan mantle metasomatism, Grégoire et al. (2001) pointed out the close similarities between the trace element contents (similar shape 
of the patterns and same positive Th-U and negative Ta anomalies) of two metasomatised spinel harzburgites from Lihir island and one metasomatised spinel harzburgite from Batan island.

All these features and comparisons are in good agreement with an origin of the two Monglo metasomatic parageneses (opx-rich and amphibole-rich) by percolation of slab-derived hydrous melts similar to the host adakite. The hydrous nature of the metasomatic melt is also supported by the similar petrographic characteristics of the Monglo metasomatic veins with those of Lihir xenoliths, i.e. evidence for hydraulic fracturing, trails of secondary inclusions and euhedral features of fibrous orthopyroxenes and crystals of amphibole. The incompatible trace element compositions of the secondary minerals suggest that the metasomatic enrichment of dunitic mantle xenoliths in Sr, Th and U and REE from La to Gd occurred during the percolation of such slab-derived hydrous melts or interaction with the host adakite during emplacement. An interesting feature of the Monglo dunites is that they bear two different metasomatic parageneses, which do not coexist in the same sample but which seem to be both related to slab-derived melts. In particular, as far as we know the amphibole-rich mineral vein assemblage has never been described before in Moho transition zone dunites. The simpler explanation would be that the degree of $\mathrm{SiO}_{2}$ saturation of the two metasomatic melts was different, that of the melt producing the opx-rich veins and pockets being higher than that of the melt forming the amphibole-rich veins and pockets. But these two melts also should have different $\mathrm{Al}_{2} \mathrm{O}_{3}, \mathrm{MgO}, \mathrm{FeO}$ and incompatible trace element compositions, as evidenced by the difference in the contents of those elements in orthopyroxenes and amphiboles which form more than $90 \%$ of the modal composition of orthopyroxene-bearing and amphibole-bearing metasomatic parageneses, respectively. That means that either: (i) slab-derived melts/fluids of contrasting compositions have metasomatised the same ophiolite mantle basement and therefore that the slab could generate different fluids/melts during its descent, or alternatively that (ii) the two vein types (amph-rich and opx-rich) are related to the circulation within the dunites of adakitic melts similar to the host lava. Indeed, experimental studies have shown that dacitic melts, and especially adakitic ones such as the Monglo host lava, may produce orthopyroxene, amphibole and phlogopite when they react with peridotitic paragenesis (e.g. [Rapp et al., 1999], [Prouteau et al., 2001] and [Prouteau and Scaillet, 2003]). An "intermediate" hypothesis is that the formation of amphibole-rich veins is related to interaction with the host lava (or a similar adakitic melt percolating the dunites before their uplift by the host lava), and that the orthopyroxene-rich veins are related to the circulation of a different type of slab-derived melt/fluid prior to the incorporation of the dunites within the host lava. The comparison of our data with the compositions of southern Kamchatka mantle peridotite xenoliths (Ishimaru et al., 2007) and with the experimental results of Prouteau and Scaillet (2003) gives strong support to this "intermediate" hypothesis. Indeed, Ishimaru et al. (2007) describe southern Kamchatka peridotite xenoliths coated by hornblendites forming thin selvages as well as veinlets cutting the xenoliths. Similar features have been observed in other sub-arc mantle xenoliths exhumed by arc magmas and especially in those from Iraya volcano, Batan island, Philippines ([Vidal et al., 1989], [Maury and Didier, 1991] and [Arai et al., 1996]). Interaction between the ultramafic xenoliths from Cerro del Fraile (Patagonia) and adakitic glass veins crosscutting them also produced metasomatic amphibole (Kilian and Stern, 2002). Moreover, the amphiboles of our study display major element compositions similar to those of interstitial and discrete amphiboles from the amphibolites selvages coating the southern Kamchatka xenoliths. Finally the major element compositions of amphiboles from Monglo dunites are also similar to those of the amphiboles produced during the 1991 Pinatubo dacite-peridotite interaction experiments of Prouteau and Scaillet (2003). 
Regarding the opx-rich veins, no coatings of orthopyroxenes forming thin selvage around xenoliths such as the amphibole selvages have been observed in the sub-arc mantle xenoliths exhumed by arc magmas. Moreover, the orthopyroxene-rich veins crosscutting the Monglo dunite xenoliths contain orthopyroxenes exhibiting complex fibrous textures similar to those of the metasomatic orthopyroxenes from Lihir and southern Kamchatka mantle xenoliths ([Grégoire et al., 2001], [McInnes et al., 2001] and [Ishimaru et al., 2007]). Such fibrous textures have been related by the authors to low-viscosity hydrous metasomatic agents. The major and trace element contents of the Monglo orthopyroxenes are also very similar to those of Lihir (Table 1; Fig. 6 and Table 2 of McInnes et al., 2001). On the other hand, their major element contents (lower $\mathrm{Al}$ and $\mathrm{Ca}$ and higher $\mathrm{Si}$ ) are different from those of the orthopyroxenes produced during the Pinatubo dacite-peridotite interaction experiments of Prouteau and Scaillet (2003). Therefore, we propose that the formation of amphibole-rich veins in the studied dunites is related to their interaction with the host Monglo adakitic magma (or a similar adakitic melt) and that the orthopyroxene-rich veins are rather related to the circulation of a different type of slab-derived melt/fluid. This interpretation implies that the amphibole-rich paragenesis has been probably the last metasomatic paragenesis to crystallize and that its formation occurred after the tectonic emplacement of the studied dunites within the crust as ophiolitic materials. However, available data do not allow us to constrain the temporal relationship between the crystallization of the opx-rich metasomatic paragenesis and the tectonic emplacement of the dunites.

Although some authors have argued that amphibole and phlogopite may be reservoirs for HFSE in subduction zones ([Hofmann, 1988], [Ionov et al., 1997] and [Bodinier et al., 1996]), we found no apparent HFSE enrichment in orthopyroxenes and amphiboles which are by far the main constituents of the Monglo metasomatic mineral assemblages. They in fact display apparent HFSE depletions (Fig. 6 and Fig. 7). In agreement with the conclusion of Grégoire et al. (2001), we propose that these depletion trends simply reflect low HFSE abundances (compared to Th, U and Sr and, in some cases, LREE) in the metasomatic slab-derived metasomatic agents (adakitic or hydrous melts). This implies that the HFSE flux through the mantle wedge was low, and that the slab-derived, hydrous melts crystallizing the orthopyroxenite-rich and the amphibole-rich veins and pockets have high LREE/HFSE and LILE/HFSE ratios, like the host adakite. This finding supports experimental data showing that Th, U and LREE mobilities in hydrous mantle melts (or fluids) are higher than those of HFSE ([Tatsumi et al., 1986], [Ayers and Eggler, 1995] and [Brenan et al., 1995]).

\section{Conclusions}

The present study indicates that the Monglo Moho transition zone spinel dunite xenoliths, which probably originated from the mantle section of an Early Cretaceous supra-subduction zone ophiolitic complex located within the Luzon arc crust, display evidence for three episodes of subduction-related melt percolation.

- The first one is evidenced by the undeformed clinopyroxene occurring in sample $01 \mathrm{c} 01$. This clinopyroxene crystallized in hot mantle conditions from a percolating calc-alkaline basaltic magma probably related to the Cretaceous supra-subduction setting of the amphibolites.

- The two other metasomatic events are evidenced by the orthopyroxene-rich and the amphibole-rich secondary parageneses occurring in four studied samples. The opx-rich paragenesis may be related to the circulation within the dunitic upper mantle of hydrous slab- 
derived melts similar to those affecting the mantle peridotite xenoliths from Papua New Guinea and Kamchatka. Finally the amphibole-rich veins are probably related to the interaction between the studied dunite xenoliths and the host adakite (or an adakitic melt similar to it).

\section{Acknowledgements}

Fieldwork and laboratory studies have been conducted with the financial and logistic help of UP-Diliman, the DUO-France program, the Ministère des Affaires Etrangères (French Embassy in Manila), the SUCRI program "Asie du Sud-Est", Université de Bretagne Occidentale, Brest and of the CNRS and Université Toulouse III. Helpful comments and reviews by Drs S. Arai and M. Roden led to significant improvements of the manuscript. We thank F. and P. de Parseval for their help with the making of the thin and thick sections and with the electron microprobe as well as R. Freydier and F. Candaudap who are in charge of the ICP-MS and associated laser items.

\section{References}

Abe et al., 1998 N. Abe, S. Arai and H. Yurimoto, Geochemical characteristics of the uppermost mantle beneath the Japan island arcs: implications for upper mantle evolution, Physics of the Earth and Planetary Interiors 107 (1998), pp. 233-247.

Andal et al., 2005 E.S. Andal, S. Arai and G.P.J. Yumul, Complete mantle section of a slow spreading ridge-derived ophiolite: an example from the Isabela ophiolite in the Philippines, Island Arc 14 (2005), pp. 272-294.

Arai, 1994 S. Arai, Characterization of spinel peridotites by olivine-spinel compositional relationships: review and interpretation, Chemical Geology 113 (1994), pp. 191-204.

Arai et al., 1996 S. Arai, M. Kida, N. Abe, A. Ninomiya and G.P. Yumul Jr., Classification of peridotite xenoliths in calc-alkaline andesite from Iraya volcano, Batan Island, the Philippines, and its genetical implications, Sciences Report Kanazawa University 41 (1996), pp. 25-45.

Arai et al., 2000 S. Arai, H. Hirai and K. Uto, Mantle peridotite xenoliths from the Southwest Japan arc: a model for the sub-arc upper mantle structure and composition of the Western Pacific rim, Journal of Mineralogical and Petrological Sciences 95 (2000), pp. 9-23.

Arai et al., 2003 S. Arai, S. Ishimaru and V.M. Okrugin, Metasomatized harzburgite xenoliths from Avacha volcano as fragments of mantle wedge of the Kamchatka arc: an implication for the metasomatic agent, Island Arc 12 (2003), pp. 233-246.

Arai et al., 2004 S. Arai, S. Takada, K. Michibayashi and M. Kida, Petrology of peridotite xenoliths from Iraya volcano, Philippines, and its implications for dynamic mantle-wedge processes, Journal of Petrology 45 (2004), pp. 369-389. 
Arculus and Wills, 1980 R.J. Arculus and K.J.A. Wills, The petrology of plutonic blocks and inclusions from the Lesser Antilles island arc, Journal of Petrology 21 (1980), pp. 743-799.

Ayers and Eggler, 1995 J.C. Ayers and D.H. Eggler, Partitioning of elements between silicate melt and $\mathrm{H}_{2} \mathrm{O}-\mathrm{NaCl}$ fluids at 1.5 and $2.0 \mathrm{GPa}$ pressure: implications for mantle metasomatism, Geochimica et Cosmochimica Acta 59 (1995), pp. 4237-4246.

Bau and Knittel, 1993 M. Bau and U. Knittel, Significance of slab-derived melts and aqueous fluids for the genesis of tholeiitic and calc-alkaline island-arc basalts: evidence from Mt. Arayat, Philippines, Chemical Geology 105 (1993), pp. 233-251.

Bodinier et al., 1996 J.L. Bodinier, C. Merlet, R.M. Bedini, F. Simien, M. Remaidi and C.J. Garrido, Distribution of niobium, tantalum, and other highly incompatible trace elements in the lithospheric mantle: the spinel paradox, Geochimica et Cosmochimica Acta 60 (1996), pp. $545-550$.

Brandon and Draper, 1996 A.D. Brandon and D.S. Draper, Constraints on the origin of the oxidation state of mantle overlying subduction zones: an example from Simcoe, Washington, USA, Geochimica et Cosmochimica Acta 60 (1996), pp. 1739-1749.

Brenan et al., 1995 J.M. Brenan, H.F. Shaw, F.J. Ryerson and D.L. Phinney, Mineral-aqueous fluid partitioning of trace elements at $900{ }^{\circ} \mathrm{C}$ and $2.0 \mathrm{GPa}$ : constraints on the trace element chemistry of mantle and deep crustal fluids, Geochimica et Cosmochimica Acta 59 (1995), pp. $3331-3350$

Coltorti et al., 1999 M.B.C. Coltorti, R.W. Hinton, F. Siena and B.G. Upton, Carbonatite metasomatism of the oceanic upper mantle: evidence from clinopyroxenes and glasses in ultramafic xenoliths of Grande Comore, Indian Ocean, Journal of Petrology 40 (1999), pp. $133-165$.

Coltorti et al., 2004 M. Coltorti, C. Bonadiman, B. Faccini, M. Grégoire, S.Y. O'Reilly and W. Powell, Discrimination of orogenic and anorogenic domains in mantle amphiboles: implications for subducted slab recycling, Lithos 99 (2007), pp. 68-84.

Coulon et al., 1984 C. Coulon, R. Clocchiatti, R.C. Maury and D. Westercamp, Petrology of basaltic xenoliths in andesitic to dacitic host lavas from Martinique (Lesser Antilles): evidence for magma mixing, Bulletin of Volcanology 4 (1984), pp. 705-734.

Defant and Drummond, 1990 M.J. Defant and M.S. Drummond, Derivation of some modern arc magmas by melting of young subducted lithosphere, Nature 347 (1990), pp. 662-665.

Defant et al., 1989 M.J. Defant, D. Jacques, R.C. Maury, J. De Boer and J.L. Joron, Geochemistry and tectonic setting of the Luzon arc, Philippines, Geological Society of America Bulletin 101 (1989), pp. 663-672.

Defant et al., 1990 M.J. Defant, R.C. Maury, J.-L. Joron, M.D. Feigenson, J. Leterrier, H. Bellon, D. Jacques and M. Richard, The geochemistry and tectonic setting of the northern section of the Luzon arc, the Philippines and Taiwan, Tectonophysics 183 (1990), pp. 187205. 
Deschamps et al., 2000 A. Deschamps, P. Monié, S. Lallemand, S.-K. Hsu and K.Y. Yeh, Evidence for a Cretaceous oceanic crust trapped in the Philippine Sea plate, Earth and Planetary Science Letters 179 (2000), pp. 503-516.

Evans, 1977 B.W. Evans, Metamorphism of alpine peridotite and serpentinite, Annual Review of Earth and Planetary Sciences 5 (1977), pp. 397-447.

Forsythe et al., 1994 L.M. Forsythe, R.L. Nielsen and M.R. Fisk, High-Field-strength element partitioning between pyroxene and basaltic to dacitic magmas, Chemical Geology 117 (1994), pp. 107-125.

Frey, 1969 F.A. Frey, Rare earth abundances in a high-temperature peridotite intrusion, Geochimica et Cosmochimica Acta 33 (1969), pp. 1429-1447.

Grégoire et al., 1997 M. Grégoire, J.P. Lorand, J.Y. Cottin, A. Giret, N. Mattielli and D. Weis, Petrology of Kerguelen mantle xenoliths: evidence of a refractory oceanic mantle percolated by basaltic melts beneath the Kerguelen archipelago, European Journal of Mineralogy 9 (1997), pp. 1085-1100.

Grégoire et al., 1998 M. Grégoire, J.Y. Cottin, N. Mattielli, A. Giret and D. Weis, The metaigneous xenoliths from Kerguelen archipelago: evidence of a continent nucleation in an oceanic setting, Contributions to Mineralogy and Petrology 133 (1998), pp. 259-283.

Grégoire et al., 2000 M. Grégoire, B.N. Moine, S.Y. O'Reilly, J.Y. Cottin and A. Giret, Trace element residence and partitioning in mantle xenoliths metasomatised by high alkaline silicate and carbonate-rich melts (Kerguelen Islands, Indian Ocean), Journal of Petrology 41 (2000), pp. $477-509$.

Grégoire et al., 2001 M. Grégoire, B.I.A. McInnes and S.Y. O'Reilly, Hydrous metasomatism of oceanic sub-arc mantle, Lihir, Papua New Guinea, Part 2. Trace element characteristics of slab-derived fluids, Lithos 59 (2001), pp. 91-108.

Grégoire et al., 2005 M. Grégoire, C. Tinguely, D.R. Bell and A.P. LeRoex, Spinel lherzolite xenoliths from the Premier kimberlite (Kaapvaal craton, South Africa): nature and evolution of the shallow upper mantle beneath the Bushveld complex, Lithos 84 (2005), pp. 185-205.

Hart and Dunn, 1993 S.R. Hart and T. Dunn, Experimental cpx/melt partitioning of 24 trace elements, Contributions to Mineralogy and Petrology 113 (1993), pp. 1-8.

Hauri et al., 1994 E.H. Hauri, T.P. Wagner and T.L. Grove, Experimental and natural partitioning of $\mathrm{Th}, \mathrm{U}, \mathrm{Pb}$ and other trace elements between garnet, clinopyroxene and basaltic melts, Chemical Geology 117 (1994), pp. 149-166.

Hofmann, 1988 A.W. Hofmann, Chemical differentiation of the Earth: the relationship between mantle, continental crust, and oceanic crust, Earth and Planetary Science Letters 90 (1988), pp. 297-314.

Ionov and Hofmann, 1995 D.A. Ionov and A.W. Hofmann, Nb-Ta-rich mantle amphiboles and micas: implications for subduction-related metasomatic trace element fractionations, Earth and Planetary Science Letters 131 (1995), pp. 341-356. 
Ionov et al., 1997 D.A. Ionov, W.L. Griffin and S.Y. O'Reilly, Volatile-bearing minerals and lithophile trace elements in the upper mantle, Chemical Geology 141 (1997), pp. 153-184.

Ionov et al., 1999 D.A. Ionov, M. Grégoire and V.S. Prikhod'ko, Feldspar-rutile-armalcolite metasomatism in post-Archean continental and oceanic upper mantle, Earth and Planetary Science Letters 165 (1999), pp. 37-44.

Ishimaru et al., 2007 S. Ishimaru, S. Arai, Y. Ishida, M. Shirasaka and V.M. Okrugin, Melting and multi-stage metasomatism in the mantle wedge beneath a frontal arc Inferred from highly depleted peridotite xenoliths from the Avacha Volcano, Southern Kamchatka, Journal of Petrology 48 (2007), pp. 395-433.

Jego et al., 2005 S. Jego, R.C. Maury, M. Polvé, G.P. Yumul Jr., H. Bellon, R.A. Tamayo Jr. and J. Cotton, Geochemistry of adakites from the Philippines: constraints on their origins, Resource Geology 55 (2005), pp. 163-187.

Johnson, 1994 K.T.M. Johnson, Experimental cpx/and garnet/melt partitioning of REE and other trace elements at high pressures; petrogenetic implications, Mineralogical Magazine 58 (1994), pp. 454-455.

Kilian and Stern, 2002 R. Kilian and C.R. Stern, Constraints on the interaction between slab melts and the mantle wedge from adakitic glass in peridotite xenoliths, European Journal of Mineralogy 14 (2002), pp. 25-36

Luhr and Aranda-Gomez, 1997 J.F. Luhr and J.J. Aranda-Gomez, Mexican peridotite xenoliths and tectonic terranes: correlations among vent location, texture, temperature, pressure, and oxygen fugacity, Journal of Petrology 38 (1997), pp. 1075-1112.

Maury and Didier, 1991 R.C. Maury and J. Didier, Xenoliths and the role of assimilation. In: J. Didier and B. Barbarin, Editors, Enclaves and granite petrology, Elsevier, Amsterdam (1991), pp. 529-542.

Maury et al., 1992 R.C. Maury, M.J. Defant and J.L. Joron, Metasomatism of the sub-arc mantle inferred from trace elements in Philippine xenoliths, Nature 360 (1992), pp. 661-663.

McDonough and Sun, 1995 W.F. McDonough and S.-S. Sun, The composition of the earth, Chemical Geology 120 (1995), pp. 223-253.

McInnes et al., 2001B.I.A. McInnes, M. Grégoire, R.A. Binns, P.M. Herzig and M.D. Hannington, Hydrous metasomatism of oceanic sub-arc mantle, Lihir, Papua New Guinea: petrology and geochemistry of fluid-metasomatised mantle wedge xenoliths, Earth and Planetary Science Letters 188 (2001), pp. 169-183.

Mercier and Nicolas, 1975 J.-C.C. Mercier and A. Nicolas, Textures and fabrics of upper mantle peridotites as illustrated by basalt xenoliths, Journal of Petrology 16 (1975), pp. 454487.

Miklius et al., 1991 A. Miklius, M.F.J. Flower, J.P.P. Huijsmans, S.B. Mukasa and P.R. Castillo, Geochemistry of lavas from Taal volcano, southwestern Luzon, Philippines: 
evidence for multiple magma supply systems and mantle source heterogeneity, Journal of Petrology 32 (1991), pp. 593-627.

Moine et al., 2001 B.N. Moine, M. Grégoire, S.Y. O'Reilly, S.M.F. Sheppard and J.Y. Cottin, High field strength element (HFSE) fractionation in the upper mantle: evidence from amphibole-rich composite mantle xenoliths from the Kerguelen Islands (Indian Ocean), Journal of Petrology 42 (2001), pp. 2145-2167.

Nixon, 1987 In: P.H. Nixon, Editor, Mantle Xenoliths, Wiley and Sons, Chichester (1987) 844 pp..

O'Reilly and Griffin, 1987 S.Y. O'Reilly and W.L. Griffin, Eastern Australia - $4000 \mathrm{~km}$ of mantle samples. In: P.H. Nixon, Editor, Mantle Xenoliths, Wiley, London (1987), pp. 267280.

Pallister et al., 1996 J.S. Pallister, R.P. Hoblitt, G.P. Meeker, R.J. Knight and D.F. Siems, Magma mixing at Mount Pinatubo: petrographic and chemical evidence from the 1991 deposits fire and mud. In: C.G. Newhall and R.S. Punongbayan, Editors, Eruptions and Lahars of Mount Pinatubo, Philippines, University Washington Press, Seattle (1996), pp. 687-731.

Paster et al., 1974 T.P. Paster, D.S. Schauwecker and L.A. Haskin, The behavior of some trace elements during solidification of the Skaergaard layered series, Geochimica et Cosmochimica Acta 38 (1974), pp. 1549-1577.

Payot et al., 2007 B. Payot, S. Jego, R.C. Maury, M. Polvé, M. Grégoire, G. Ceuleneer, R.A.J. Tamayo, G.A.J. Yumul, H. Bellon and J. Cotten, The oceanic substratum of Northern Luzon: evidence from xenoliths within the Monglo adakite (Philippines), Island Arc 16 (2007), pp. 276-290.

Polvé et al., 2007 M. Polvé, R.C. Maury, S. Jego, H. Bellon, A. Margoum, G.A.J. Yumul, B. Payot, R.A.J. Tamayo, M. Grégoire and J. Cotten, Temporal geochemical evolution of Neogene magmatism in the Baguio gold-copper mining district (Northern Luzon, Philippines), Resource Geology 57 (2007), pp. 197-218.

Prouteau and Scaillet, 2003 G. Prouteau and B. Scaillet, Experimental constraints on the origin of the 1991 Pinatubo dacite, Journal of Petrology 44 (2003), pp. 2203-2241.

Prouteau et al., 2001 G. Prouteau, B. Scaillet, M. Pichavant and R.C. Maury, Evidence of mantle metasomatism by hydrous silicic melts derived from subducted oceanic crust, Nature 410 (2001), pp. 197-200.

Pubellier et al., 2004 M. Pubellier, C. Monnier, R. Maury and R.A.J. Tamayo, Plate kinematics, origin and tectonic emplacement of supra-subduction ophiolites in SE Asia, Tectonophysics 392 (2004), pp. 9-36.

Rapp et al., 1999 R.P. Rapp, N. Shimizu, M.D. Norman and G.S. Applegate, Reaction between slab-derived melts and peridotite in the mantle wedge: experimental constraints at 3.8 GPa, Chemical Geology, 160 (1999), pp. 891-931. 
Sajona et al., 1994 F.G. Sajona, H. Bellon, R.C. Maury, M. Pubellier, J. Cotten and C. Rangin, Magmatic response to abrupt changes in geodynamic settings: Pliocene-Quaternary calc-alkaline and Nb-enriched lavas from Mindanao (Philippines), Tectonophysics, 237 (1994), pp. 47-72.

Sajona et al., 1996 F.G. Sajona, R.C. Maury, H. Bellon, J. Cotten and M.J. Defant, High field strength element enrichment of Pliocene-Pleistocene island arc basalts, Zamboanga Peninsula, Western Mindanao (Philippines), Journal of Petrology 37 (1996), pp. 693-726.

Sajona et al., 1997 F.G. Sajona, H. Bellon, R.C. Maury, M. Pubellier, R.D. Quebral, J. Cotten, F.E. Bayon, E. Pagado and P. Pamatian, Tertiary and Quaternary magmatism in Mindanao and Leyte (Philippines): geochronology, geochemistry and tectonic setting, Journal of Asian Earth Sciences 15 (1997), pp. 121-153.

Sajona et al., 2000a F.G. Sajona, R.C. Maury, G. Prouteau, J. Cotten, P. Schiano, H. Bellon and L. Fontaine, Slab melt as metasomatic agent in island arc magma mantle sources, Negros and Batan (Philippines), Island Arc 9 (2000), pp. 472-486.

Sajona et al., 2000b F.G. Sajona, R.C. Maury, M. Pubellier, J. Leterrier, H. Bellon and J. Cotten, Magmatic source enrichment by slab-derived melts in a young post-collision setting, central Mindanao (Philippines), Lithos 54 (2000), pp. 173-206.

Schiano et al., 1995 P. Schiano, R. Clocchiatti, N. Shimizu, R.C. Maury, K.P. Jochum and A.W. Hofmann, Hydrous silica-rich melts in the sub-arc mantle and their relationship with erupted arc lavas, Nature 377 (1995), pp. 595-600.

Smith et al., 1999D. Smith, J.C.A. Riter and S.A. Mertzman, Water-rock interactions, orthopyroxene growth, and Si-enrichment in the mantle: evidence in xenoliths from the Colorado Plateau, southwestern United States, Earth and Planetary Science Letters 167 (1999), pp. 45-54.

Sun and McDonough, 1989 S.-S. Sun and W.F. McDonough, Chemical and isotopic systematics of oceanic basalts: implications for mantle composition and processes. In: A.D. Saunders and M.J. Norry, Editors, Magmatism in the Ocean Basins 42, Geological Society Special Publication (1989), pp. 313-345.

Tamayo, 2001 R.A.J. Tamayo Jr., Caractérisation pétrologique et géochimique, origines et évolutions géodynamiques des ophiolites des Philippines, Thèse de Doctorat, Université de Bretagne Occidentale, Brest (2001) 318 pp..

Tamayo et al., 2004 R.A.J. Tamayo, R.C. Maury and G.P.J. Yumul, The early geodynamic evolution of the Philippine archipelago: constraints from the geochemistry of ophiolite complexes, Bulletin de la Société géologique de France 175 (2004), pp. 443-460.

Tamesis et al., 1982 E.V. Tamesis, R.A.J. Lorentz, R.V. Pascual and E.M. Dizon, Stratigraphy and geologic structures of the Central Valley Basin, Luzon, Philippines. In: G.R. Balce and A.S. Zanoria, Editors, Geology and Tectonics of the Luzon-Marianas Region. Proceedings CCOP-IOC SEASTAR Workshop, Manila (1982), pp. 83-111. 
Tatsumi et al., 1986 Y. Tatsumi, D.L. Hamilton and R.W. Nesbitt, Chemical characteristics of fluid phase released from a subducted lithosphere and origin of arc magmas: evidence from high-pressure experiments and natural rocks, Journal of Volcanology and Geothermal Research 29 (1986), pp. 293-309.

Vidal et al., 1989 P. Vidal, C. Dupuy, R. Maury and M. Richard, Mantle metasomatism above subduction zones: trace element and radiogenic isotope in xenoliths from Batan Island (Philippines), Geology 17 (1989), pp. 1115-1118.

Yumul et al., 1995 G.P. Yumul, L.P.J. De Silva, R.J.R. Claveria and R.T. Datuin, Evolution from a marginal basin to a mature island arc: the Baguio Mining District, Luzon, Philippines, Journal of the Geological Society of the Philippines 47 (1995), pp. 95-105.

Yumul et al., 2000 G.P. Yumul, C.B. Dimalanta and F.T. Jumawan, Geology of southern Zambales ophiolite complex, Luzon Philippines, Island Arc 9 (2000), pp. 542-555. 


\section{Figures}

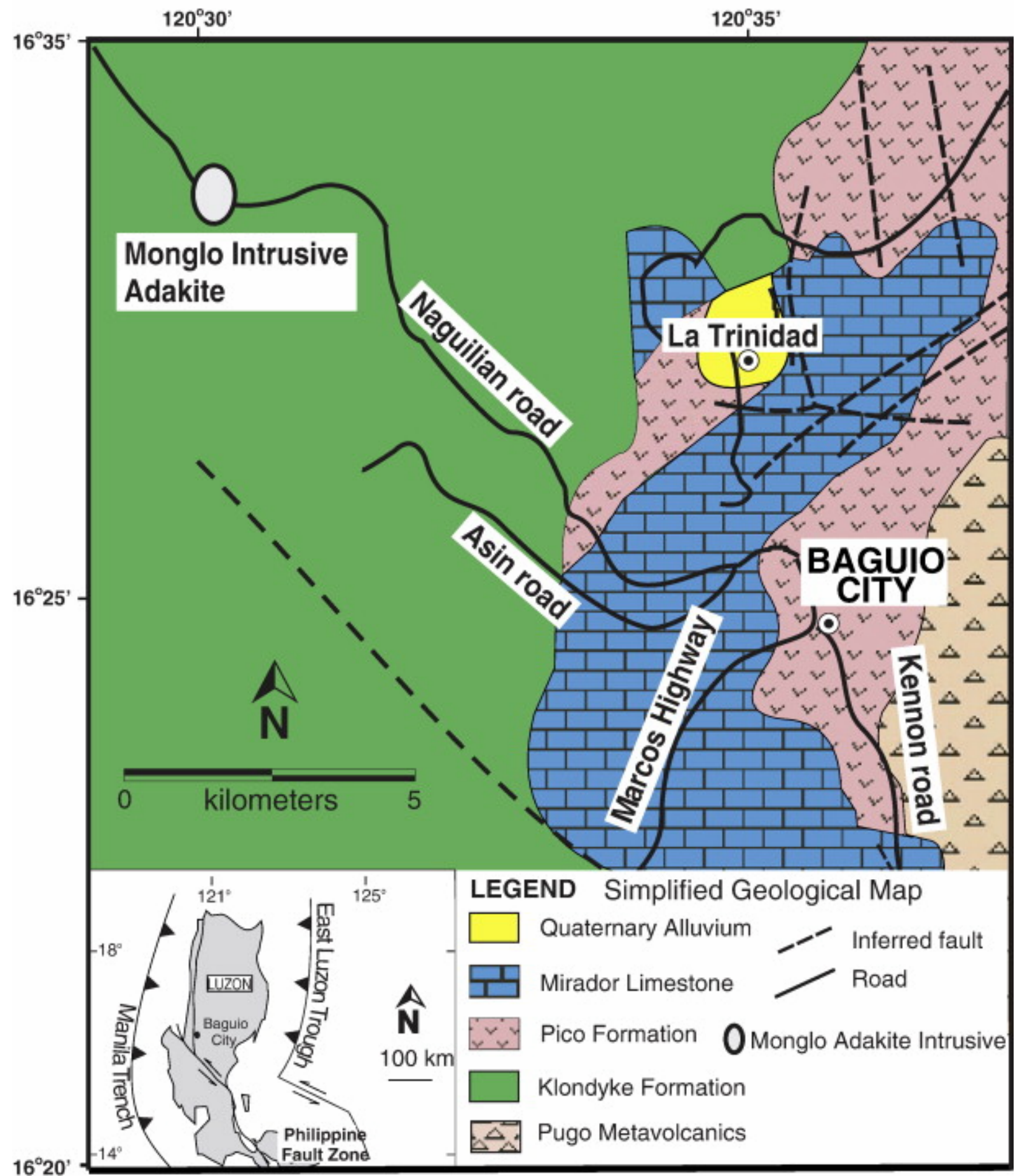

Fig. 1. Simplified geological map of the Baguio area in Northern Luzon, adapted from Yumul et al. (1995). The main tectonic features of Northern Luzon are shown in the inset. The ages of the geological formations are as follows: Pugo Metavolcanics: Eocene; Pico Formation and Klondyke Formation: Middle to Late Miocene; Mirador Limestone: Late Miocene. 

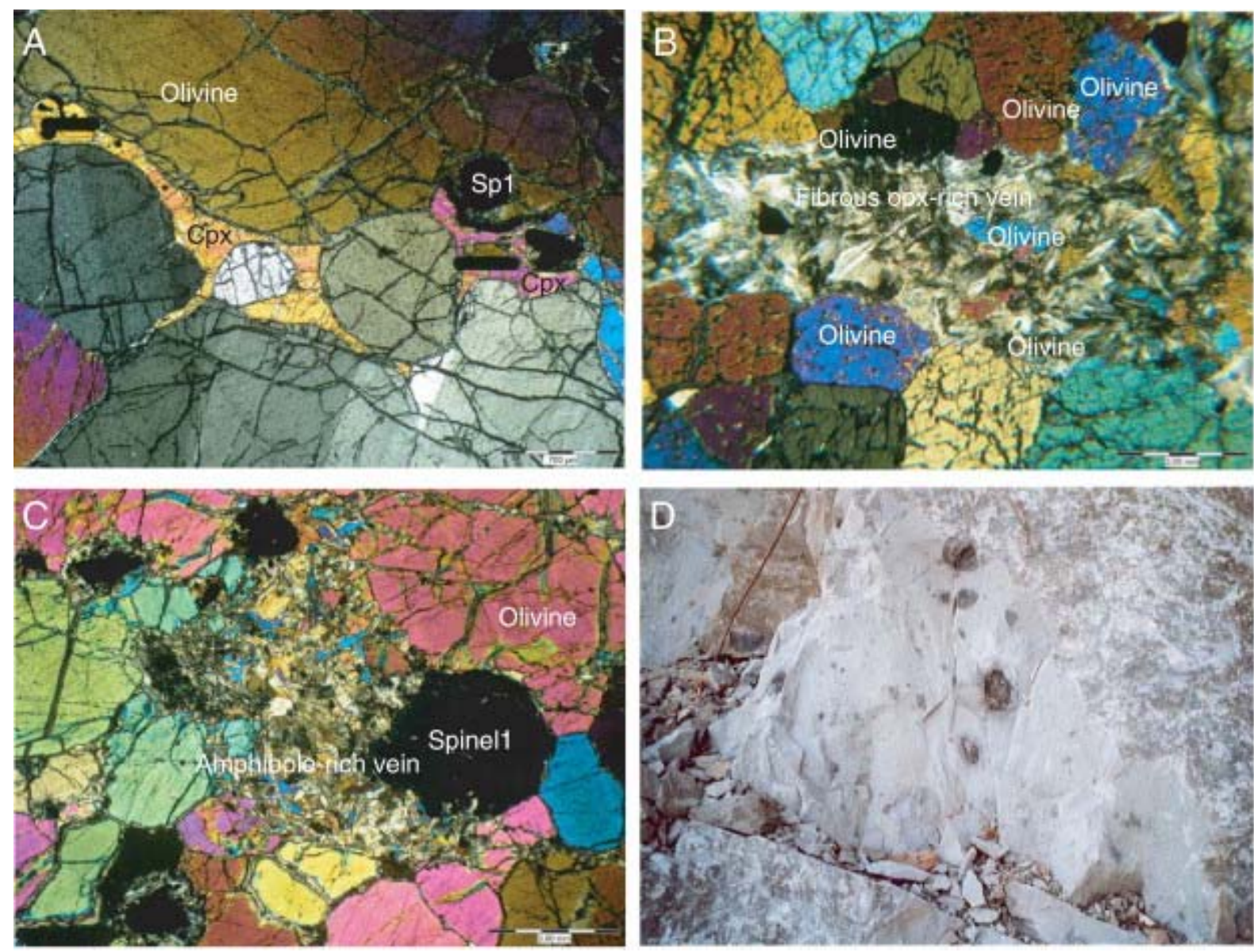

Fig. 2. A), B) and C): Photomicrographs of the Monglo spinel dunite xenoliths: A) interstitial clinopyroxene between big olivine crystals (sample 01c01); B) a fibrous orthopyroxene-rich vein cross-cutting a dunite (sample $08 \mathrm{jb}$ ). Note that a relict dunitic olivine occurs within the vein; C) an amphibole-rich vein (perpendicular view) cross-cutting a dunite (sample 08je). D): Field photograph of the Monglo quarry adakite and its xenoliths. The surface shown by the photograph is ca. $1 \mathrm{~m}^{2}$. The host lava (white) contains numerous mafic and ultramafic xenoliths (grey to black) ranging in size from 1 to $10 \mathrm{~cm}$. 


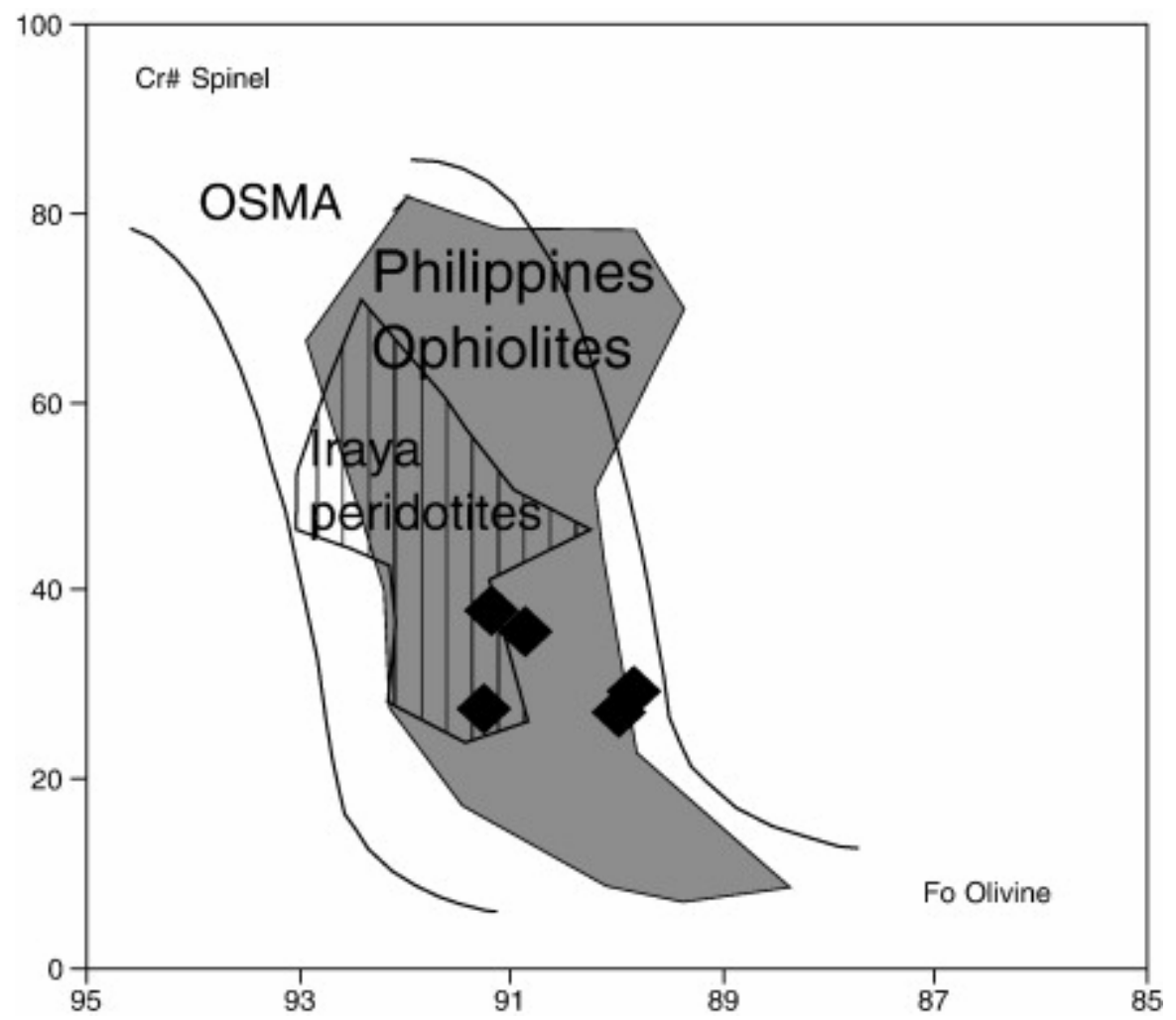

Fig. 3. The spinels of the Monglo dunite xenoliths are plotted in the Cr\# spinel vs Fo olivine diagram and they lie within the Olivine-Spinel Mantle Array (OSMA) (Arai, 1994). They also display similarities with the spinels occurring within the Iraya peridotites (Batan Island, Philippines; Arai et al., 2004) and those from the peridotites from the Philippines ophiolites ([Tamayo, 2001] and [Andal et al., 2005]). 

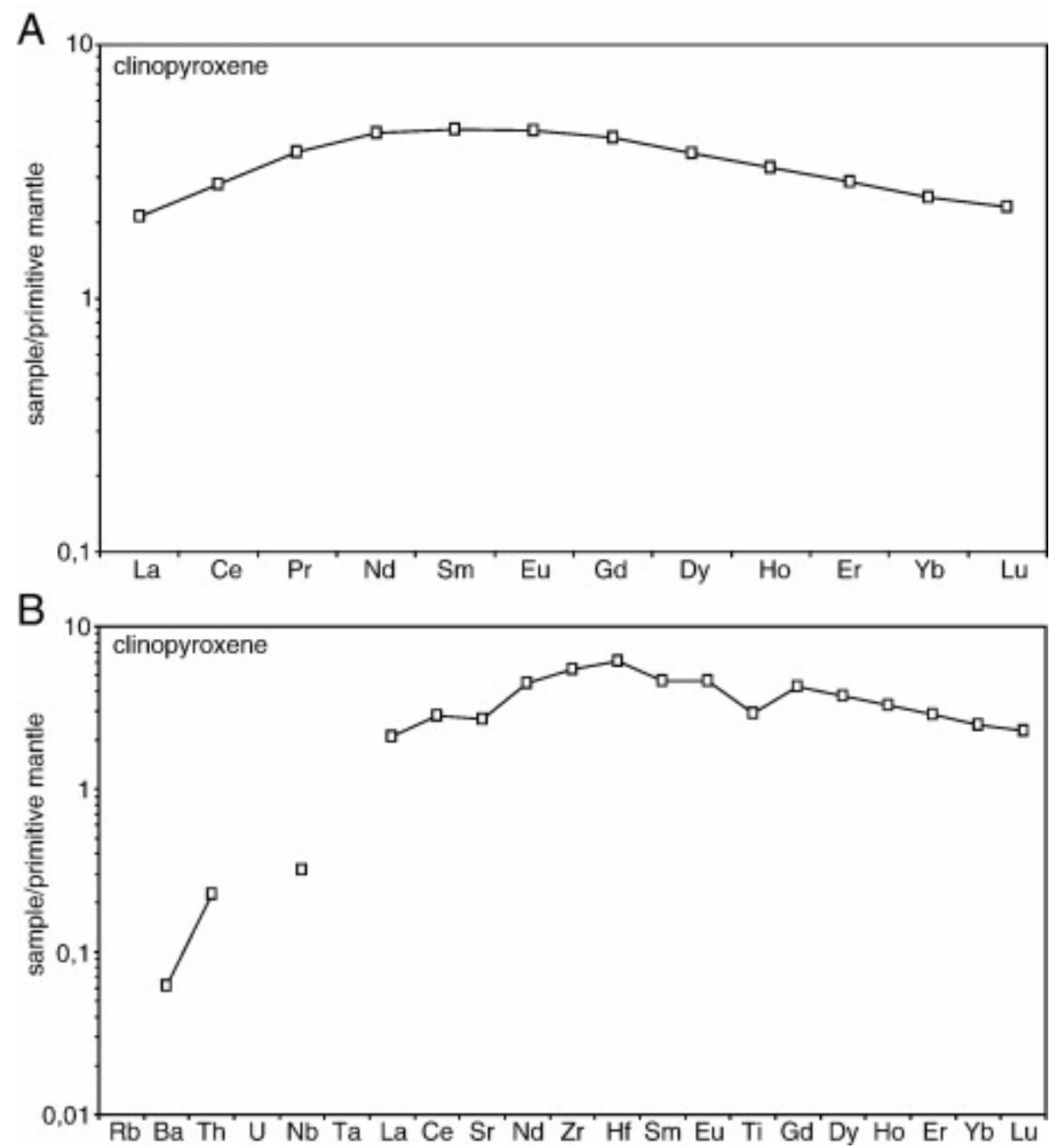

Fig. 4. Primitive mantle-normalized REE patterns (A) and incompatible trace element patterns (B) for clinopyroxene of Monglo dunite xenolith 01c01. Normalizing values after McDonough and Sun (1995). In primitive mantle-normalized trace element plots, the sequence of elements is related to their decreasing incompatibility during partial melting of upper-mantle peridotites (Sun and McDonough, 1989). 

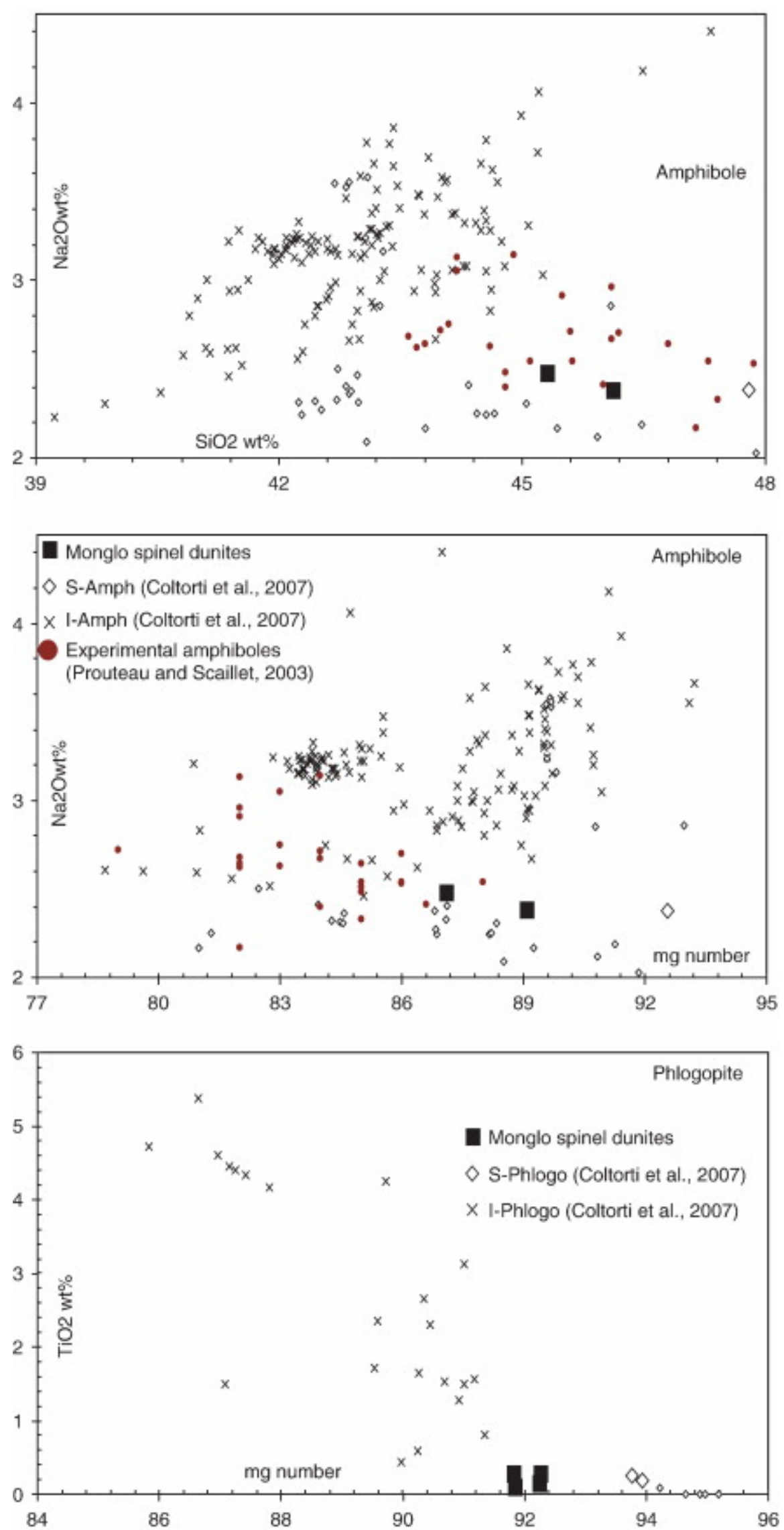

Fig. 5. Diagrams $\mathrm{Na}_{2} \mathrm{O}$ vs $\mathrm{SiO}_{2}$ and $\mathrm{Na}_{2} \mathrm{O}$ vs $\mathrm{Mg}$ number $\left(100 \times \mathrm{Mg} / \mathrm{Mg}+\mathrm{Fe}_{\text {total }}\right)$ for amphiboles and $\mathrm{TiO}_{2}$ vs $\mathrm{Mg}$ number for phlogopites of the Monglo spinel dunites (filled 
squares) compared with the S-Amph and S-Phlogo (diamonds - subduction mantle amphiboles and phlogopites; the biggest diamond corresponds to the amphibole from Lihir peridotite; Grégoire et al., 2001),the I-Amph (crosses - intraplate mantle amphiboles) defined by Coltorti et al. (2007) and the experimental amphiboles of Prouteau and Scaillet (2003) filled circles, see Section 5.2 for explanation).

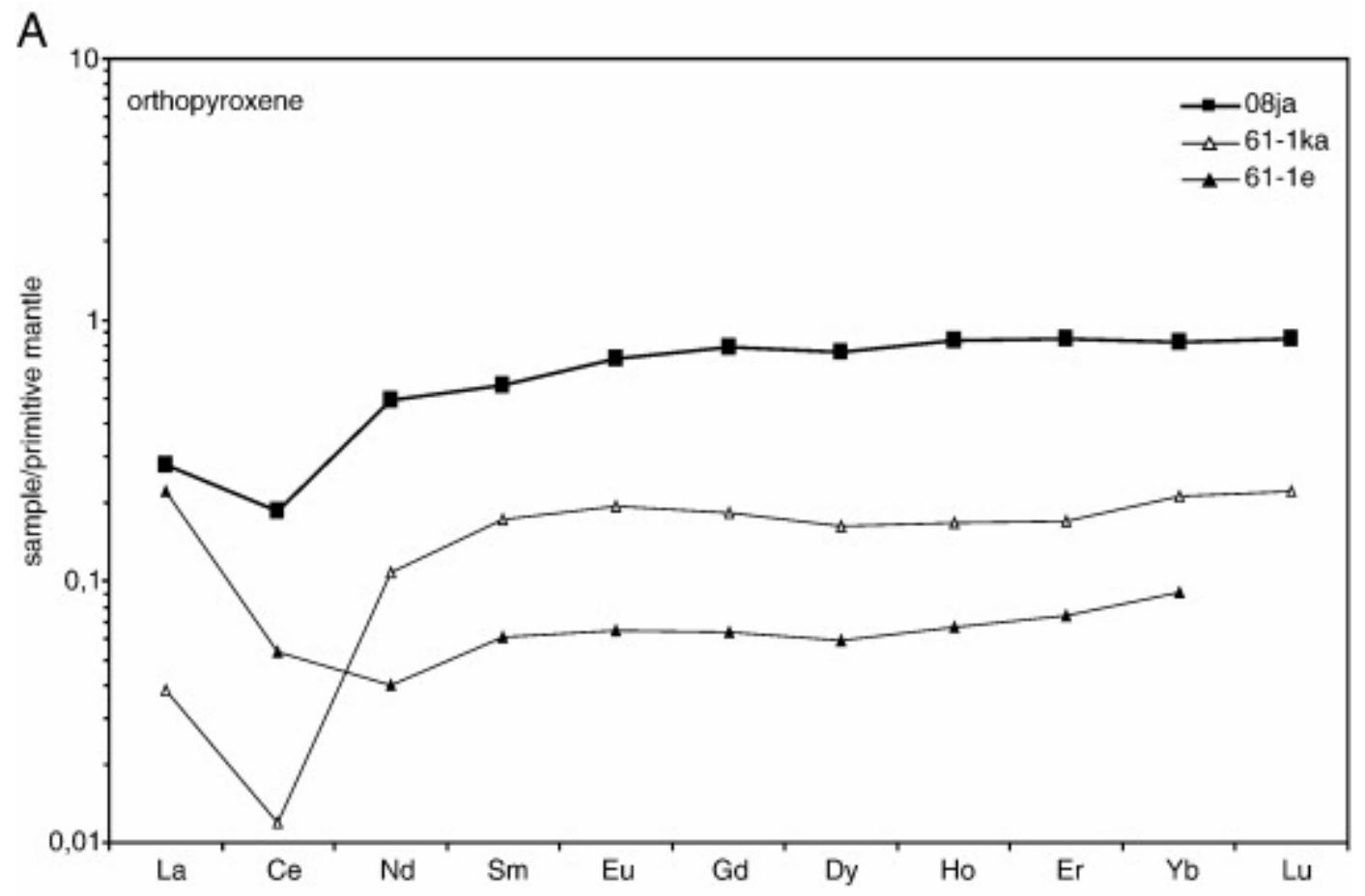

B

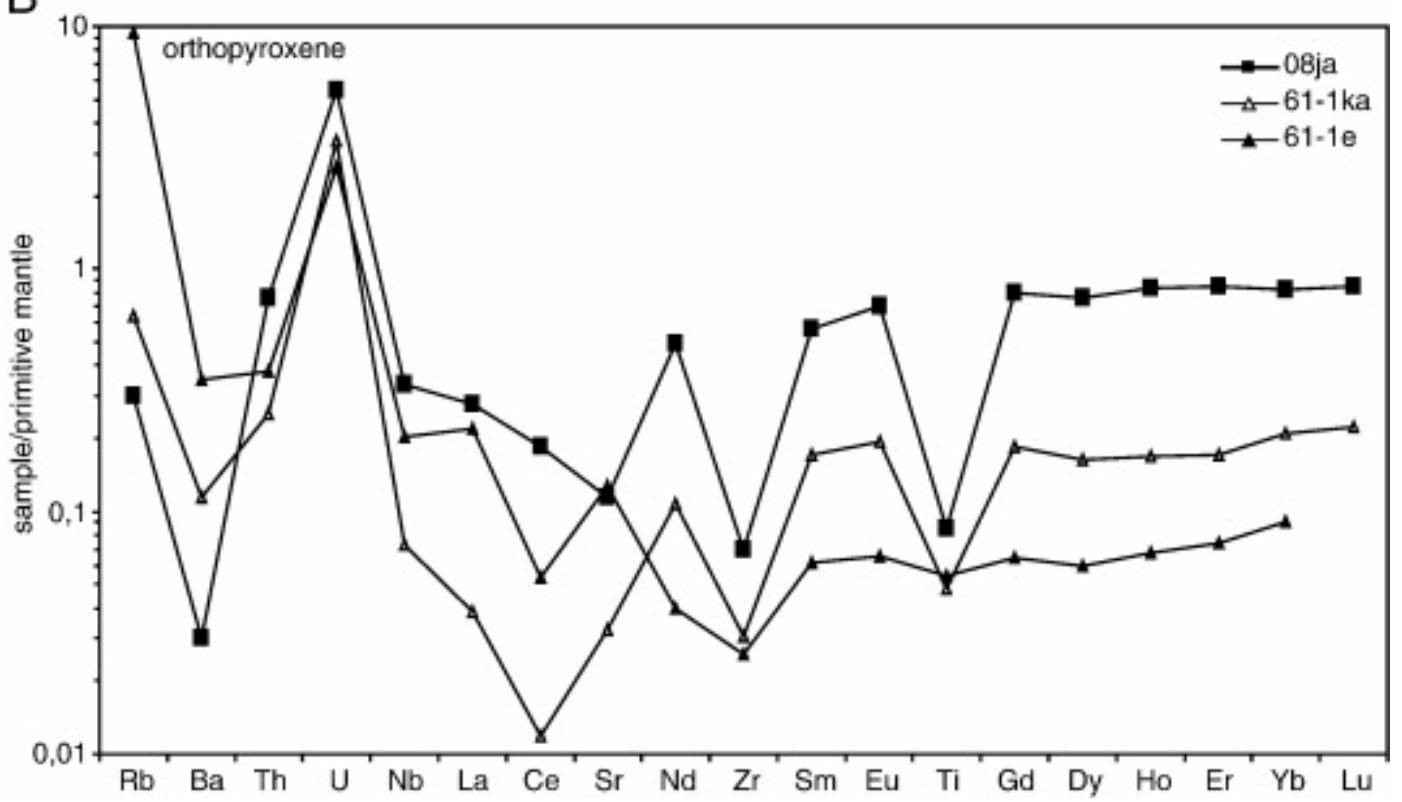

Fig. 6. Primitive mantle-normalized REE patterns (A) and incompatible trace element patterns (B) for fibrous orthopyroxenes of Monglo dunite xenolith 08ja compared to those of fibrous orthopyroxenes in spinel peridotite xenoliths from Lihir Island (samples 61-1ka and 61-1e, Papua New Guinea, Grégoire et al., 2001). Normalizing values after McDonough and Sun (1995). 


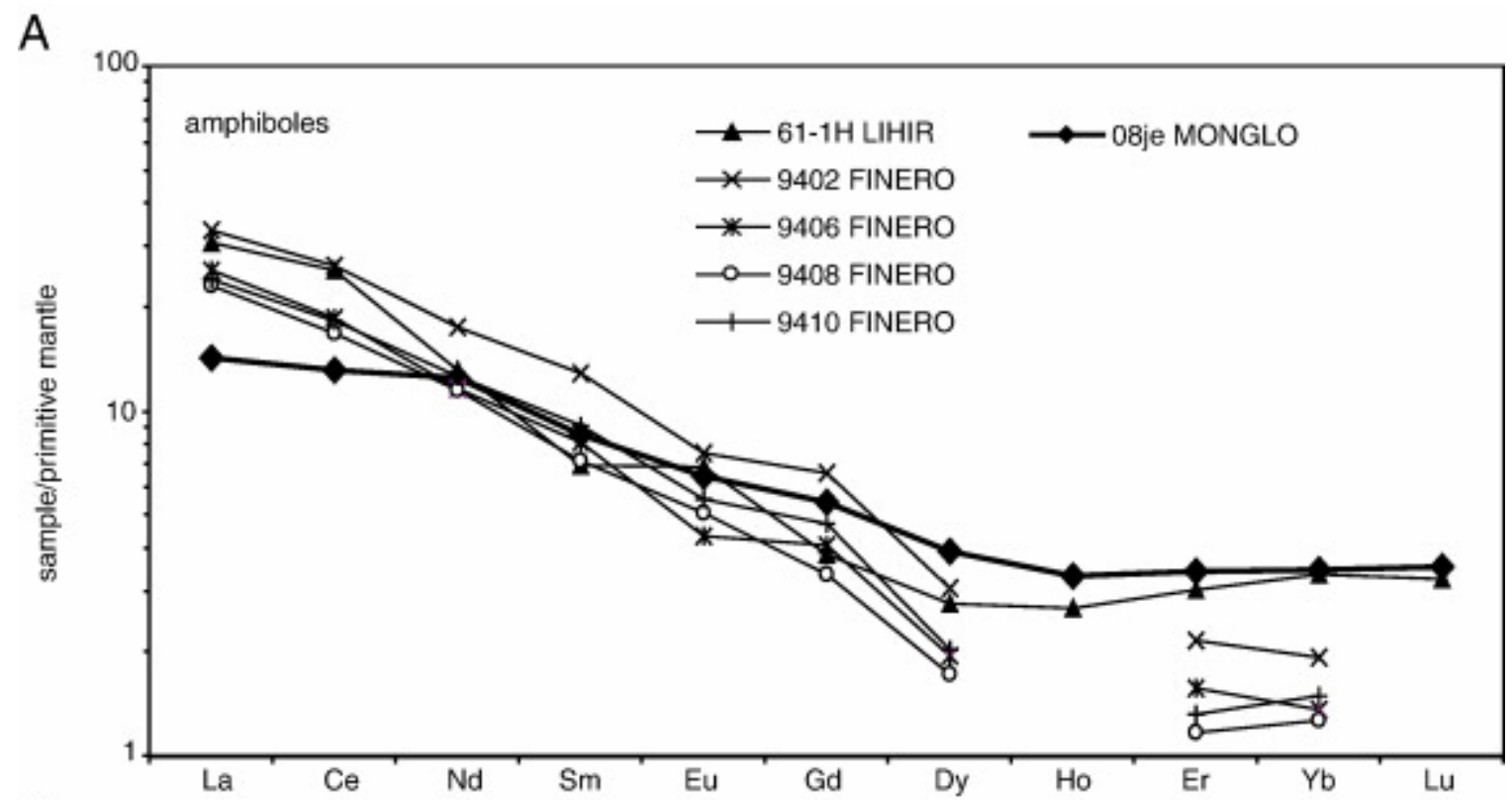

B

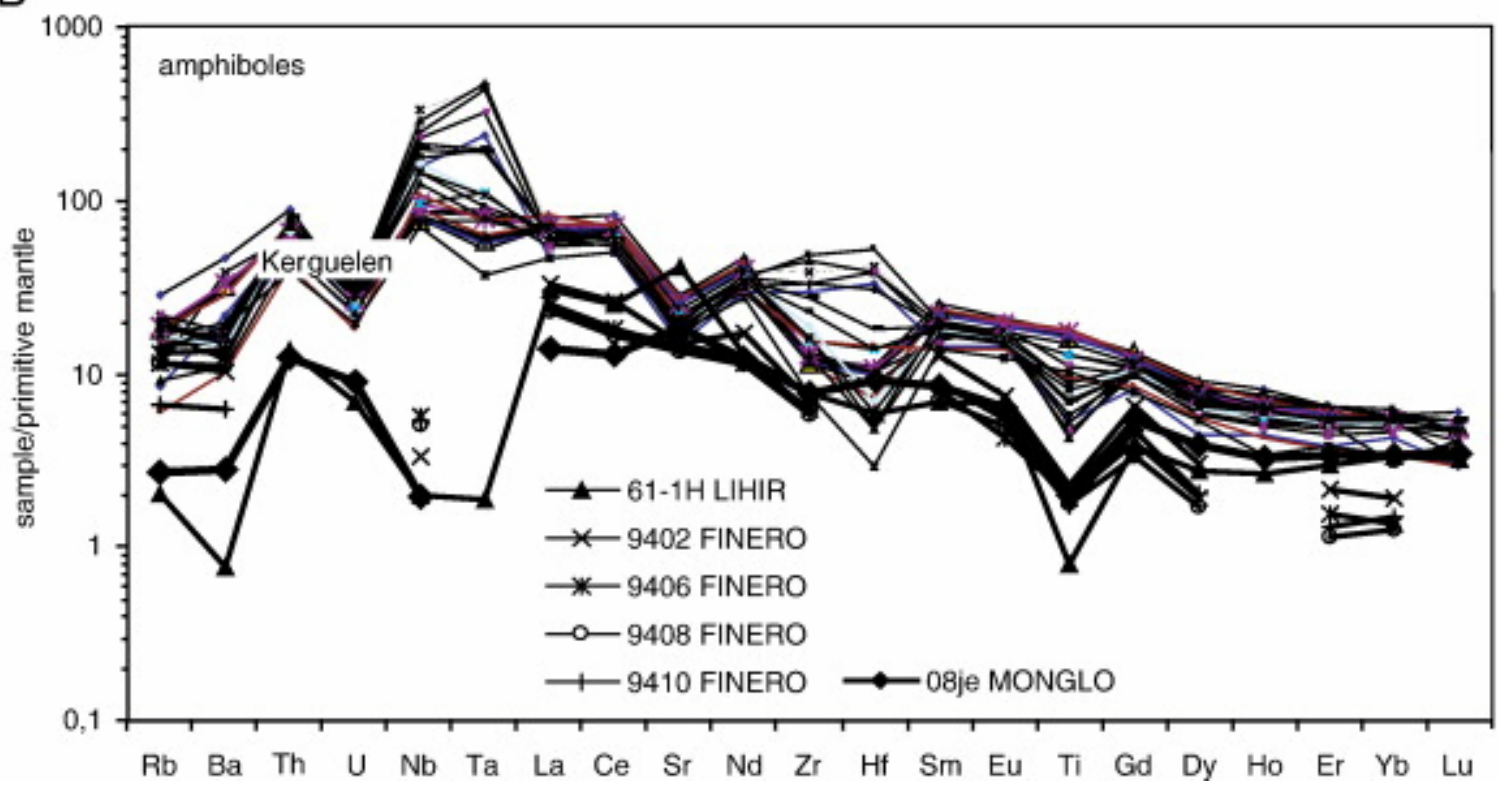

Fig. 7. Primitive mantle-normalized REE patterns (A) and incompatible trace element patterns (B) for amphiboles of Monglo dunite xenolith 08je compared to that of amphiboles in spinel peridotite xenoliths from Lihir Island (samples 61-1h, Papua New Guinea, Grégoire et al., 2001) those of amphiboles from peridotites from the Finero massif (samples 9402, 9406, 9408 and 94010, Italian alps, Coltorti et al., 2007) and those of amphiboles from the mantle xenoliths from the Kerguelen Islands ([Grégoire et al., 200] and [Moine et al., 2001]). Amphiboles from Lihir and Finero are Subduction mantle amphiboles (S-type of Coltorti et al., 2007) while those of Kerguelen are typical Intraplate mantle amphiboles (I-type of Coltorti et al., 2007). Normalizing values after McDonough and Sun (1995). 

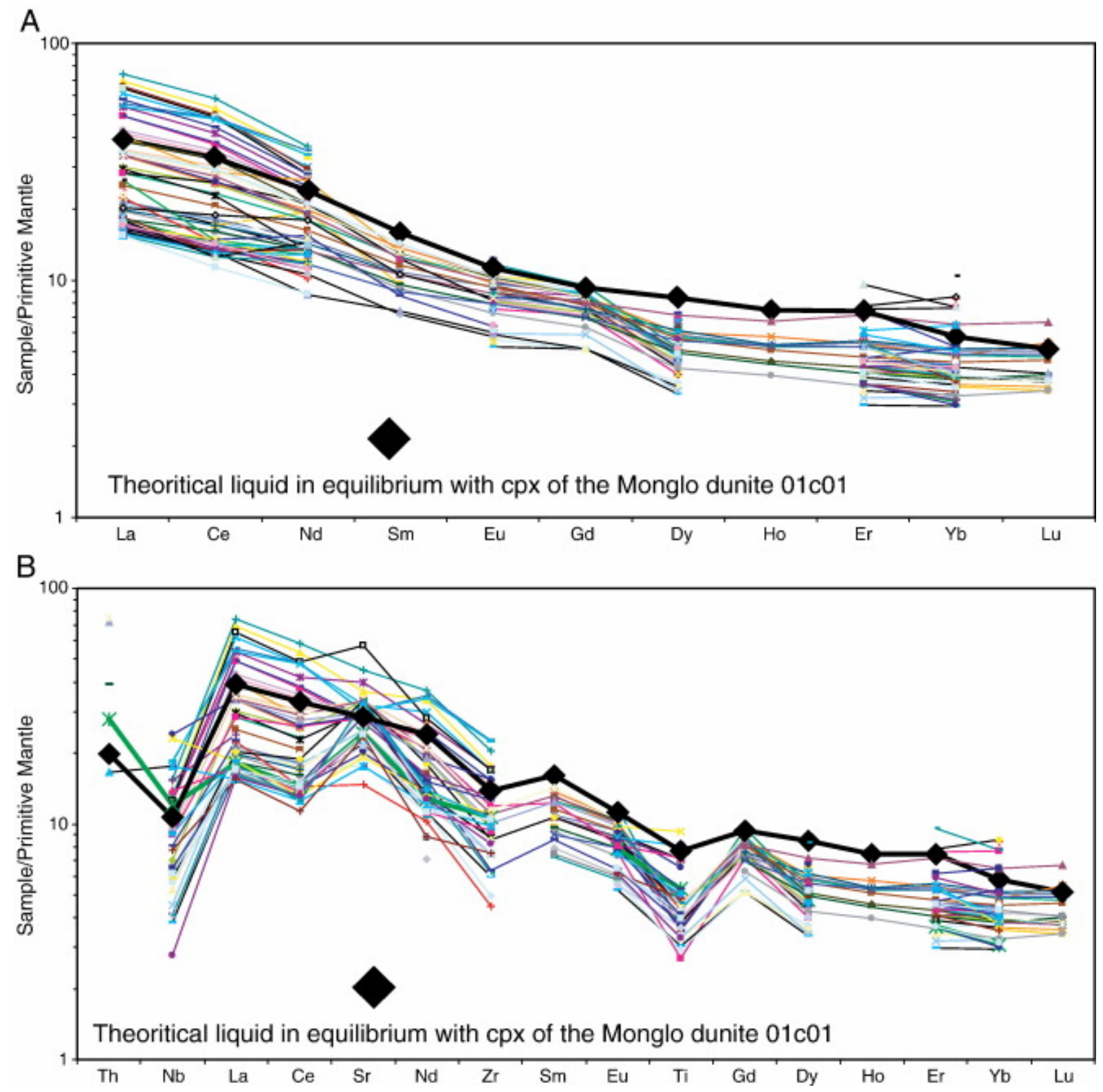

Fig. 8. Primitive mantle-normalized REE patterns (A) and incompatible trace element patterns (B) for the theoretical liquid in equilibrium with cpx of the Monglo dunite $01 \mathrm{c01}$ (big diamonds, see Section 5.2 for the method of calculation) compared with the REE and TE contents of some basaltic rocks from the Luzon Arc (data from [Bau and Knittel, 1993], [Yumul et al., 2000], [Schiano et al., 1995], [Sajona et al., 1994], [Sajona et al., 1996], [Sajona et al., 1997], [Sajona et al., 2000a], [Sajona et al., 2000b], [Miklius et al., 1991] and [Pallister et al., 1996]). Normalizing values after McDonough and Sun (1995). 


\section{Tables}


Table 1. : Averaged major element compositions of the minerals of the Monglo spinel dunites

\begin{tabular}{|c|c|c|c|c|c|c|c|c|c|c|c|c|c|c|c|c|}
\hline & & $\mathrm{SiO}_{2}$ & $\mathrm{TiO}_{2}$ & $\mathrm{Al}_{2} \mathrm{O}_{3}$ & $\mathrm{Cr}_{2} \mathrm{O}_{3}$ & $\mathrm{FeO}_{t}$ & MnO & MgO & $\mathrm{CaO}$ & $\mathrm{Na}_{2} \mathrm{O}$ & $\mathbf{K}_{2} \mathbf{O}$ & $\mathrm{NiO}$ & ZnO & TOTAL & Mg\# & Cr\# \\
\hline 08Je-amphibole & $n=11$ & 46.13 & 0.51 & 13.02 & 0.16 & 4.24 & 0.10 & 19.47 & 11.18 & 2.38 & 0.23 & 0.11 & 0.02 & 97.55 & 89.10 & - \\
\hline 08Je-opx1 & $n=1$ & 54.86 & 0.05 & 4.11 & 0.14 & 6.76 & 0.17 & 32.99 & 0.21 & - & - & 0.10 & - & 99.39 & 89.69 & - \\
\hline 08Je-Olivine1 & $n=5$ & 40.89 & - & - & 0.01 & 9.86 & 0.18 & 48.96 & 0.06 & - & - & 0.37 & - & 100.33 & 89.84 & - \\
\hline 08Je-phlogopite & $n=4$ & 39.69 & 0.26 & 17.68 & 0.47 & 3.76 & 0.04 & 23.72 & 0.01 & 1.78 & 7.78 & 0.21 & 0.03 & 95.44 & 91.84 & - \\
\hline 08Je-spinel1 core & $n=4$ & 0.01 & 0.24 & 36.93 & 23.03 & 23.11 & 0.26 & 15.17 & - & - & - & 0.35 & 0.18 & 99.28 & 53.92 & 29.49 \\
\hline 08Je-spinel1 rim & $n=3$ & 0.03 & 0.42 & 27.01 & 30.13 & 27.47 & 0.26 & 13.44 & - & - & - & 0.39 & 0.23 & 99.39 & 46.58 & 42.80 \\
\hline 08Je-spinel2 green & $n=1$ & - & 0.01 & 63.53 & 2.68 & 11.80 & 0.20 & 20.42 & - & - & - & 0.41 & 0.19 & 99.23 & 75.52 & 2.75 \\
\hline 08Jf amphibole & $n=4$ & 45.32 & 0.21 & 13.56 & 0.23 & 4.90 & 0.13325 & 18.59 & 11.60 & 2.47 & 0.24 & 0.16 & & 97.41 & 87.12 & - \\
\hline 08Jf opx 1 & $n=1$ & 54.73 & 0.07 & 4.51 & 0.66 & 5.28 & 0.16 & 34.18 & 0.19 & - & 0.01 & 0.19 & - & 99.98 & 92.02 & - \\
\hline 08Jf-Olivine1 & $n=8$ & 40.99 & - & - & 0.01 & 9.68 & 0.15 & 48.87 & 0.31 & - & - & 0.32 & 0.04 & 100.37 & 90.00 & - \\
\hline 08Jf-phlogopite & $n=1$ & 40.19 & 0.14 & 16.93 & 1.19 & 3.51 & 0.09 & 23.44 & 0.02 & 1.17 & 8.50 & 0.24 & 0.05 & 95.47 & 92.26 & - \\
\hline 08Jf spinel1 core & $n=6$ & 0.05 & 0.09 & 39.73 & 21.99 & 20.23 & 0.15 & 16.88 & - & - & - & 0.25 & 0.12 & 99.49 & 59.79 & 27.07 \\
\hline 08Jf spinel1 rim & $n=3$ & 0.20 & 0.17 & 31.16 & 30.28 & 21.93 & 0.18 & 15.13 & - & - & - & 0.26 & 0.24 & 99.55 & 55.15 & 39.46 \\
\hline 08Je-spinel2 green & $n=1$ & - & - & 64.13 & 2.83 & 12.80 & 0.15 & 20.42 & - & - & - & 0.11 & 0.12 & 100.55 & 73.98 & 2.87 \\
\hline 08Jb olivine 1 & $n=4$ & 41.16 & - & - & - & 8.50 & 0.10 & 49.68 & 0.27 & - & - & 0.31 & - & 100.03 & 91.24 & \\
\hline $08 \mathrm{Jb}$ fibrous opx 2 & $n=3$ & 57.49 & - & 1.67 & 0.06 & 5.22 & 0.17 & 35.52 & 0.07 & - & - & - & - & 100.20 & 92.39 & \\
\hline 08Jb spinelle1 & $n=3$ & 0.07 & 0.10 & 36.99 & 20.85 & 26.23 & 0.16 & 13.84 & - & - & - & 0.57 & 0.21 & 99.00 & 48.46 & 27.43 \\
\hline 08Ja phlogopite & $n=1$ & 40.19 & 0.08 & 14.94 & 0.92 & 3.78 & - & 23.93 & 0.02 & 0.88 & 8.83 & 1.27 & 0.57 & 95.43 & 91.85 & \\
\hline 08Ja olivine1 & $n=8$ & 41.23 & - & - & 0.02 & 8.92 & 0.19 & 49.76 & 0.07 & - & - & 0.39 & 0.25 & 100.83 & 90.86 & \\
\hline 08Ja fibrous opx2 & $n=12$ & 58.69 & 0.01 & 0.49 & 0.10 & 3.60 & 0.08 & 37.10 & 0.09 & - & 0.01 & 0.09 & 0.01 & 100.25 & 94.84 & \\
\hline
\end{tabular}




\begin{tabular}{|c|c|c|c|c|c|c|c|c|c|c|c|c|c|c|c|c|}
\hline & & $\mathrm{SiO}_{2}$ & $\mathrm{TiO}_{2}$ & $\mathrm{Al}_{2} \mathrm{O}_{3}$ & $\mathrm{Cr}_{2} \mathrm{O}_{3}$ & $\mathrm{FeO}_{t}$ & MnO & MgO & $\mathrm{CaO}$ & $\mathrm{Na}_{2} \mathrm{O}$ & $\mathbf{K}_{2} \mathbf{O}$ & $\mathrm{NiO}$ & $\mathrm{ZnO}$ & TOTAL & Mg\# & Cr\# \\
\hline 08-Ja dark gray spinel1 & $n=4$ & 0.03 & 0.14 & 34.38 & 28.29 & 21.70 & 0.33 & 14.23 & - & - & - & 0.22 & 0.06 & 99.39 & 53.90 & 35.56 \\
\hline 08-Ja light gray spinel2 & $n=6$ & 0.05 & 0.44 & 8.75 & 33.60 & 46.97 & 0.35 & 8.21 & - & - & - & 0.74 & 0.25 & 99.36 & 23.76 & 72.04 \\
\hline $01 \mathrm{c} 01 \mathrm{cpx}$ & $n=16$ & 51.68 & 0.65 & 4.43 & 1.47 & 1.56 & 0.04 & 15.06 & 24.09 & 0.86 & - & - & - & 99.85 & 94.50 & - \\
\hline 01c01 olivine & $n=7$ & 41.25 & - & - & 0.02 & 8.62 & 0.17 & 49.95 & 0.17 & - & - & 0.37 & 0.01 & 100.56 & 91.17 & - \\
\hline 01c01 phlogopite & $n=1$ & 41.11 & 0.27 & 14.81 & 1.15 & 3.62 & 0.08 & 24.28 & 0.05 & 1.10 & 8.44 & 0.33 & 0.07 & 95.31 & 92.28 & \\
\hline $01 \mathrm{c} 01$ spinel core & $n=9$ & 0.05 & 0.23 & 34.61 & 31.73 & 16.80 & 0.19 & 15.49 & - & - & - & 0.17 & 0.19 & 99.47 & 62.17 & 38.08 \\
\hline 01c01 spinel rim & $n=3$ & 0.07 & 0.59 & 15.51 & 29.78 & 39.80 & 0.32 & 10.20 & - & - & - & 0.38 & 0.14 & 96.79 & 31.36 & 56.28 \\
\hline $01 \mathrm{c} 01$ small near big one & $n=1$ & 0.02 & - & 48.61 & 15.38 & 15.93 & 0.17 & 18.49 & - & - & - & 0.29 & 0.38 & 99.28 & 67.42 & 17.51 \\
\hline
\end{tabular}

$\mathrm{Mg} \#=100 \times \mathrm{Mg} / \mathrm{Mg}+\mathrm{Fe}_{\text {total }}$ and $\mathrm{Cr} \#=100 \times \mathrm{Cr} / \mathrm{Cr}+\mathrm{Al}$. 
Table 2. : Averaged trace element compositions of clinopyroxenes, amphiboles and fibrous orthopyroxenes (see text for explanations)

\begin{tabular}{|c|c|c|c|}
\hline Sample & 01c1 (cpx) & 08ja (fibrous opx) & 08je (amphibole) \\
\hline Number of crystals analysed & $N=4$ & $n=3$ & $n=6$ \\
\hline $\mathrm{CaO}$ (wt.\%) & & $0.11(0.09)$ & \\
\hline $\mathrm{FeO}($ wt.\%) & & $4.05(3.60)$ & \\
\hline $\mathrm{Ti}$ & 3546 & 103 & 2402 \\
\hline $\mathrm{V}$ & 286 & 18 & 189 \\
\hline $\mathrm{Ni}$ & 155 & 897 & 1056 \\
\hline $\mathrm{Rb}$ & $\mathrm{Bd}$ & 0.18 & 1.64 \\
\hline $\mathrm{Sr}$ & 54 & 2.29 & 376 \\
\hline $\mathrm{Zr}$ & 58 & 0.73 & 83 \\
\hline $\mathrm{Nb}$ & 0.22 & 0.23 & 1.35 \\
\hline $\mathrm{Ba}$ & 0.41 & 0.20 & 19 \\
\hline $\mathrm{La}$ & 1.36 & 0.18 & 9.21 \\
\hline $\mathrm{Ce}$ & 4.72 & 0.31 & 22 \\
\hline $\mathrm{Nd}$ & 5.61 & 0.62 & 16 \\
\hline $\mathrm{Sm}$ & 1.89 & 0.23 & 3.48 \\
\hline $\mathrm{Eu}$ & 0.71 & 0.11 & 0.99 \\
\hline $\mathrm{Gd}$ & 2.34 & 0.43 & 2.94 \\
\hline Dy & 2.52 & 0.51 & 2.64 \\
\hline Ho & 0.49 & 0.13 & 0.50 \\
\hline Er & 1.26 & 0.37 & 1.51 \\
\hline $\mathrm{Yb}$ & 1.10 & 0.37 & 1.52 \\
\hline $\mathrm{Lu}$ & 0.15 & 0.06 & 0.24 \\
\hline $\mathrm{Hf}$ & 1.73 & 0.06 & 2.64 \\
\hline $\mathrm{Ta}$ & $\mathrm{Bd}$ & 0.03 & $\mathrm{Bd}$ \\
\hline Th & 0.02 & 0.06 & 1.00 \\
\hline $\mathrm{U}$ & $\mathrm{Bd}$ & 0.11 & 0.18 \\
\hline
\end{tabular}

Regarding the $\mathrm{CaO}$ and $\mathrm{FeO}$ contents we have reported the ICP-MS values recalculated in wt. $\%$ and in the brackets the electron microprobe values. 